\title{
NAFLD in Some Common Endocrine Diseases: Prevalence, Pathophysiology, and Principles of Diagnosis and Management
}

\author{
Amedeo Lonardo ${ }^{1, *(1)}$, Alessandro Mantovani ${ }^{2}$, Simonetta Lugari ${ }^{3}$ and Giovanni Targher ${ }^{2}(\mathbb{C})$ \\ 1 Operating Unit Internal Medicine-Ospedale Civile di Baggiovara-AOU, 41125 Modena, Italy \\ 2 Section of Endocrinology, Diabetes and Metabolism, Department of Medicine, University and Azienda \\ Ospedaliera Universitaria Integrata of Verona, 37126 Verona, Italy; alessandro.mantovani@univr.it (A.M.); \\ giovanni.targher@univr.it (G.T.) \\ 3 Department of Biomedical, Metabolic and Neural Science, University of Modena and Reggio Emilia, \\ 41125 Modena, Italy; simonetta.lugari@libero.it \\ * Correspondence: a.lonardo@libero.it
}

Received: 23 May 2019; Accepted: 4 June 2019; Published: 11 June 2019

\begin{abstract}
Secondary nonalcoholic fatty liver disease (NAFLD) defines those complex pathophysiological and clinical consequences that ensue when the liver becomes an ectopic site of lipid storage owing to reasons other than its mutual association with the metabolic syndrome. Disorders affecting gonadal hormones, thyroid hormones, or growth hormones (GH) may cause secondary forms of NAFLD, which exhibit specific pathophysiologic features and, in theory, the possibility to receive an effective treatment. Here, we critically discuss epidemiological and pathophysiological features, as well as principles of diagnosis and management of some common endocrine diseases, such as polycystic ovary syndrome (PCOS), hypothyroidism, hypogonadism, and GH deficiency. Collectively, these forms of NAFLD secondary to specific endocrine derangements may be envisaged as a naturally occurring disease model of NAFLD in humans. Improved understanding of such endocrine secondary forms of NAFLD promises to disclose novel clinical associations and innovative therapeutic approaches, which may potentially be applied also to selected cases of primary NAFLD.
\end{abstract}

Keywords: GH deficiency; hypogonadism; hypothyroidism; PCOS

\section{Introduction}

When the liver becomes an ectopic deposit of fatty substrates, which is not one of the physiologic functions of this organ, a cascade of pathophysiological and clinical consequences will ensue. Collectively, these complex metabolic, hepatic, and extra-hepatic consequences are referred to as nonalcoholic fatty liver disease (NAFLD) [1,2]. While the global burden of NAFLD has been elucidated [3-5], the pharmacological treatment of NAFLD remains investigational [6,7]. This therapeutic uncertainty partly reflects our incomplete understanding of the ultimate driving forces which promote the development and the progression of NAFLD.

The metabolic syndrome defines a set of cardio-metabolic risk factors, primarily comprising increased visceral adiposity, which amplifies insulin resistance, and predisposes to impaired glucose tolerance or type 2 diabetes, atherogenic dyslipidemia, and arterial hypertension. These metabolic abnormalities tend to cluster in a given patient, so that the presence of each of them strongly predicts the development of other abnormalities over time [8]. Moreover, it is widely appreciated that disorders causing deranged serum concentrations of sex hormones, thyroid hormones, and growth hormones (GH) may also predispose to the development of metabolic syndrome [9-13]. This further substantiates 
the assertion that visceral adiposity and metabolic syndrome are closely linked with, and in control of, multiple hormonal driving forces.

Primary NAFLD may precede, coexist or follow the occurrence of the metabolic syndrome and its individual features [14]. However, NAFLD may also be secondary to myriads of other causes, such as chronic use of steatogenic drugs, viral infections, parenteral nutrition, hereditary conditions, and surgery [15]. Among these causes of secondary NAFLD, some endocrine diseases [e.g., polycystic ovary syndrome (PCOS), primary hypothyroidism, hypogonadism, and GH deficiency (GHD)] also rank among the first and best characterized risk factors for the development and progression of NAFLD [16,17]. For example, hypothyroidism-induced NAFLD recently raised considerable scientific interest as a distinct disease entity, owing to its strong epidemiological basis and unique pathophysiology; it also serves as a disease model which may help in identifying innovative therapeutic avenues virtually amenable to be extrapolated to manage selected cases of primary NAFLD [18,19].

On these grounds, the present review article briefly discusses epidemiological features, pathophysiological mechanisms, and principles of diagnosis and management of NAFLD in patients with PCOS, primary hypothyroidism, hypogonadism, or GHD. It should be noted that NAFLD is an increasingly prevalent and burdensome liver disease, which is probably overlooked by endocrinologists. Conversely, hepatologists may tend to dismiss underlying endocrine derangements in individuals exhibiting seemingly primary NAFLD. Therefore, our specific aims are to sensitize practicing physicians, clinical endocrinologists, and hepatologists to promptly recognize those forms of NAFLD, which may occur secondary to some common endocrine diseases. In addition, we also aim at prompting researchers to identify these secondary NAFLD forms as a naturally occurring disease model, characterization of which may promote a better understanding of pathophysiological mechanisms and management strategies of all forms of NAFLD, notably including selected cases with primary NAFLD.

\section{Polycystic Ovary Syndrome}

\subsection{Epidemiology and Diagnosis of PCOS}

PCOS is the most common form of anovulatory infertility, which affects as many as up to nearly $10 \%$ of women of reproductive age in Europe and worldwide, and may also lead to additional health problems in middle and late adulthood. Indeed, women with PCOS have an increased long-term risk of developing type 2 diabetes, hypertension, and coagulation disorders, as well as increased cardiovascular morbidity and mortality [20-22]. In 1935, Stein and Leventhal, two American gynecologists, were first in describing PCOS by reporting a series of patients exhibiting the syndromic tetrad of ovarian cysts, chronic anovulation, obesity, and hirsutism [23].

Based on the 2003 Rotterdam diagnostic criteria [24], PCOS is currently diagnosed by the presence of at least two out of the following three features: clinical and/or biochemical hyperandrogenism, chronic oligo-anovulation, and polycystic ovarian morphology, after exclusion of other endocrine disorders, such as hyperprolactinemia, thyroid dysfunction, late-onset congenital adrenal hyperplasia, or androgen-secreting tumors. It should be pointed out that obesity, which was a component of the early descriptions of the syndrome, is no longer considered a diagnostic feature of PCOS [24,25]. However, affecting up to $\sim 40 \%$ of these patients, obesity is indeed a common finding in PCOS. The Rotterdam diagnostic criteria introduced at least three different PCOS phenotypes, subsequently named "classic" (i.e., presence of hyperandrogenism and chronic oligo-anovulation, with or without polycystic ovarian morphology), "ovulatory" (i.e., presence of hyperandrogenism and polycystic ovarian morphology), and "normo-androgenic" (i.e., presence of chronic oligo-anovulation and polycystic ovarian morphology) [24]. As one of the results of this high clinical heterogeneity, women with different phenotypes of PCOS may also differ in terms of co-existent metabolic disorders. In particular, the risk of insulin resistance and metabolic syndrome is greatest in women with PCOS exhibiting the "classic" phenotype, intermediate in those with the "ovulatory" phenotype, and lowest in those with the "normo-androgenic" phenotype $[25,26]$. Therefore, physicians must be aware that pharmacological 
approaches to these patients should be personalized by taking into account the specific characteristics of each individual patient with PCOS. Whether or not these individual differences in both insulin resistance/metabolic syndrome and androgen excess may also affect the risk of either having NAFLD at baseline or developing incident NAFLD over time is not entirely clear, although the currently available evidence suggests that this may indeed be the case.

\subsection{Epidemiological Evidence Linking PCOS to NAFLD}

An ever-increasing number of cross-sectional and case-control studies strongly suggest that the prevalence of NAFLD (in most cases diagnosed with ultrasonography) is remarkably increased in young women with PCOS, regardless of overweight/obesity and other features of the metabolic syndrome (such as extensively reviewed in Reference [27]). In these studies, the prevalence of NAFLD in women with PCOS ranges from approximately $35 \%$ to $70 \%$ compared to approximately $20 \%$ to $30 \%$ in age- and body mass index (BMI)-matched control women [27]. Notably, some small case-control studies performed at tertiary gastroenterology centers also documented that PCOS is highly common among young women with biopsy-proven NAFLD [28-30]. Indeed, among these patients, the prevalence of PCOS ranged from approximately $50 \%$ to $70 \%$, and these women were also more likely to have the most severe histological forms of NAFLD (i.e., nonalcoholic steatohepatitis (NASH), advanced fibrosis, or cirrhosis) [28-30]. With regard to the association between PCOS and the histological severity of NAFLD, Setji et al. [28] were first in demonstrating the association of biopsy-proven fibrosing NASH with PCOS in their retrospective chart review study of 200 United States patients with PCOS.

An updated and comprehensive meta-analysis of 17 observational studies, involving a total of 2734 women with PCOS and 2561 healthy women of similar age and BMI, recently confirmed that young women with PCOS had an almost two-fold higher risk of prevalent NAFLD than control women (fixed-effects odds ratio (OR) 2.25, 95\% confidence intervals (CI) $1.95-2.60 ; I^{2}=57 \%$ ) [31]. Moreover, women with PCOS and hyperandrogenism (i.e., the "classic" phenotype) had a significantly higher risk of prevalent NAFLD, even after adjustment for BMI and other potential confounding factors. Conversely, normo-androgenic women with PCOS did not seem to have a higher prevalence of NAFLD when compared to control women [31]. As reported previously, it is reasonable to believe that this differential impact of the PCOS phenotypes on the risk of developing NAFLD is largely due to the fact that the risk of insulin resistance and metabolic syndrome is greatest among PCOS women with the "classic" phenotype, intermediate among those with the "ovulatory" phenotype, and lowest among those with the "normo-androgenic" phenotype.

Notably, the 13 studies included in the aforementioned meta-analysis, which performed multivariable logistic regression analyses adjusting for age, BMI, serum triglycerides, and insulin resistance, confirmed that increased serum androgen levels (i.e., total testosterone and free androgen index) were independently associated with NAFLD in women with PCOS [31]. Overall, PCOS women with NAFLD also had significantly higher total testosterone levels (mean difference: $0.40 \mathrm{nmol} / \mathrm{L}, 95 \% \mathrm{CI}$ $0.29-0.50 \mathrm{nmol} / \mathrm{L}$ ) and, especially, higher free androgen index (mean difference: 4.46, 95\% CI 3.53-5.39) than their counterparts without NAFLD [31]. In line with these findings, in a small case-control study involving young women with PCOS $(n=29)$ and healthy control women $(n=22)$ who were matched for age, BMI, and waist circumference, Jones et al. [32] found that women with PCOS and hyperandrogenism had markedly higher intra-hepatic fat content (detected by magnetic resonance spectroscopy (MRS)) than normo-androgenic PCOS women and healthy controls (mean hepatic fat content: $12.9 \%$ vs. $0.6 \%$ vs. $1.9 \%$, respectively). These inter-group differences in intra-hepatic fat content remained statistically significant even after adjustment for BMI, visceral adipose tissue, and insulin resistance [32]. In a large case-control study, involving 275 non-obese women with PCOS and 892 non-obese controls, Kim et al. found that women with PCOS had a higher prevalence of ultrasound-diagnosed NAFLD than those without NAFLD ( $5.5 \%$ vs. $2.8 \%)$, and that, in women with PCOS, the presence of hyperandrogenemia (i.e., higher free testosterone or free androgen index) was associated with NAFLD, independent of age, BMI, insulin resistance, or glycemic control [33]. 
Recently, Kumarendran et al. [34], utilizing a large United Kingdom (UK) primary care database, performed a population-based retrospective cohort study which included more than 63,000 women with PCOS and $\sim 121,000$ age-, BMI-, and location-matched control women registered between 2000 and 2016. Of interest, these authors were able to show that women with PCOS had an increased incidence of NAFLD (hazard ratio 2.23, 95\% CI 1.86-2.66), even after adjustment for age, BMI, and dysglycemia. Further to increased BMI and dysglycemia, these authors also identified hyperandrogenism as an additional risk factor potentially contributing to the development of NAFLD in women with PCOS [34]. Other studies reported higher free androgen index and lower plasma sex-hormone-binding globulin (SHBG) levels in PCOS women with NAFLD than in those without NAFLD [35]. However, other investigators did not find any significant difference in free androgen index or SHBG levels between PCOS women with and without NAFLD [36,37]. Future studies in larger cohorts of carefully characterized PCOS women are needed to better elucidate this issue.

\subsection{Putative Pathophysiological Mechanisms Linking PCOS with NAFLD}

A detailed discussion of the putative underlying biological mechanisms through which PCOS may promote the development and progression of NAFLD is beyond the scope of this review article and was more extensively addressed by our group elsewhere [27]. Briefly, there is now an accumulating body of clinical and experimental evidence suggesting that PCOS and NAFLD share common pathogenic mechanisms and are part of a more complex and intriguing network of genetic, clinical, and pathophysiological features (i.e., metabolic, endocrine, and inflammatory abnormalities) [27]. As shown in Figure 1, it is plausible to assume that the pathophysiological mechanisms underpinning the increased risk of NAFLD in PCOS are multi-factorial, involve both genetic and acquired factors, and are likely to represent a complex interplay between abdominal adiposity/overweight/obesity, systemic insulin resistance, chronic inflammation, and hyperandrogenism [27]. Some of these biological actors, such as abdominal adiposity/overweight/obesity and insulin resistance are acknowledged to be major players in the general pathophysiology of NAFLD [27,38]. Experimental studies also supported a key role of insulin in the regulation of ovarian androgen biosynthesis in PCOS. In fact, multiple studies showed that insulin stimulates androgenesis by increasing ovarian androgen production and decreasing hepatic SHBG synthesis. The cellular mechanisms via which insulin regulates androgenesis are not well understood, but potential pathways were proposed [39]. Experimentally, it was demonstrated that insulin acts through its own receptor in ovarian theca cells. Specific blockade of phosphoinositide 3-kinase (PI3K) in normal human theca cells markedly inhibits the combined insulin and luteinizing hormone (LH) stimulation of P450c17 activity [40]. It was also demonstrated that insulin stimulates P450c17 activity through some players of the mitogen-activated protein kinase (MAPK) pathway, such as MAP kinase-activated protein kinase-3 (MKK3/p38) and MAP kinase-activated protein kinase-4/c-Jun N-terminal kinase (MKK4/JNK) [41]. On the other hand, specific inhibition of mitogen-activated protein kinase/extracellular signal-regulated kinase (MEK/ERK), a component of the MAPK insulin pathway, may increase P450c17 activity. Since insulin stimulates MEK/ERK activity, such a defect would not contribute to insulin-stimulated androgen production, but it could promote androgenesis or its responsiveness to stimulation with insulin (via PI3K, MKK3/p38, and MKK4/JNK pathways) and LH/adrenocorticotropic hormone (ACTH) [39-42].

Several studies showed that androgens may induce adipose tissue dysfunction, with adverse effects on lipid metabolism, insulin sensitivity, and adipose tissue expansion [43]. Therefore, androgen-mediated adipose lipotoxicity could represent an important mechanism leading to liver injury in hyperandrogenic PCOS women. Furthermore, in vitro studies also support a direct adverse effect of androgens on hepatic lipid metabolism in women, with testosterone increasing lipogenic gene expression and de novo lipogenesis in human hepatocytes from female, but not male, donors [43]. As discussed below in another section of the article, this sexually dimorphic role of androgens in human metabolic disease is an emerging topic, with female androgen excess and male androgen deficiency sharing an overlapping adverse metabolic phenotype, including abdominal 
overweight/obesity, dysglycemia, insulin resistance, and NAFLD [43]. However, further studies are needed to better elucidate how hyperandrogenism may directly promote the development and progression of NAFLD in PCOS, and to establish whether treatment with anti-androgenic drugs may reduce the risk of NAFLD in both lean and obese women with PCOS.

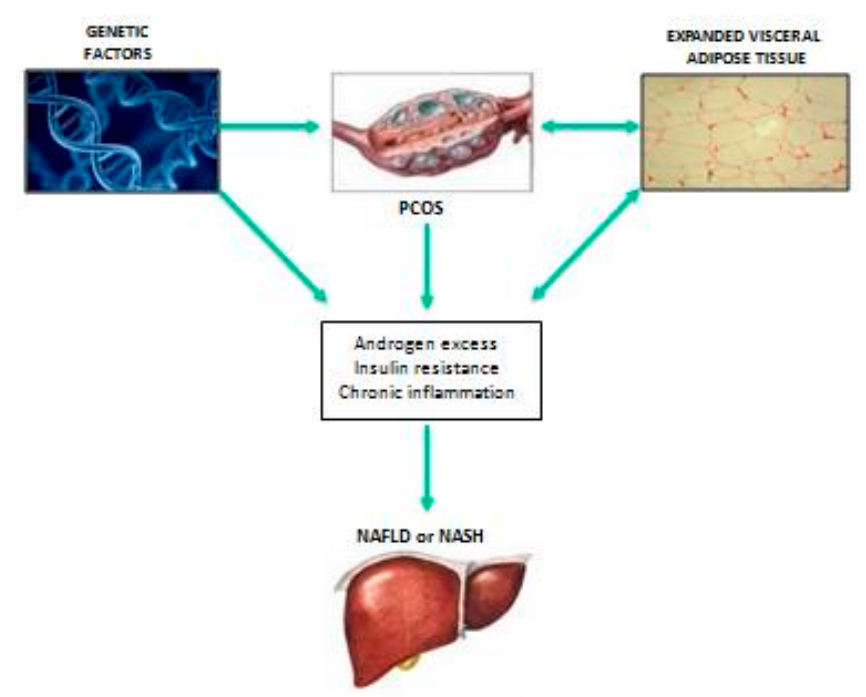

Figure 1. Schematic representation of the putative mechanisms linking polycystic ovary syndrome (PCOS) with the development of nonalcoholic fatty liver disease (NAFLD). NAFLD and nonalcoholic steatohepatitis (NASH) secondary to PCOS are a unique model of endocrine liver disease featuring progressive liver disease in young women with amenorrhea.

In the last few years, several abnormalities of ovarian angiogenesis with dysregulation of multiple angiogenic factors (including vascular endothelial growth factor, angiopoietins, platelet-derived growth factor, transforming growth factor- $\beta$, and basic fibroblast growth factor) were also described in women with PCOS [43]. Thus, it was suggested that this angiogenic factor dysregulation may play a role in PCOS pathophysiology, and might also contribute to ovulatory dysfunction, subfertility, and ovarian hyperstimulation syndrome, which are commonly observed in PCOS women. Based on this fascinating topic, future experimental studies will be needed to explore the potential role of PCOS-related angiogenic factor dysregulation in the development of NAFLD.

\subsection{Screening and Therapeutic Approaches to NAFLD in PCOS}

Given the growing prevalence of NAFLD in young women with PCOS, who are also at risk of developing the most advanced histological forms of NAFLD over time, we firmly believe that the population of young women with PCOS should definitely be considered for systematic screening for NAFLD, especially whenever obesity and clinical/biochemical hyperandrogenism are also present. The optimal method to routinely screen for NAFLD patients with PCOS is currently unclear. However, given the poor sensitivity of serum liver enzyme levels in detecting NAFLD [38], we suggest that, in patients with PCOS, liver ultrasonography and transient elastography (Fibroscan) combined with the use of non-invasive fibrosis markers (e.g., either NAFLD fibrosis score or Fibrosis-4 score) should be used as first-line options for identifying both those individuals with NAFLD and those with suspected NASH to submit to liver biopsy [38]. Moreover, all patients with PCOS should undergo regular follow-up examinations not only for liver-related complications but also for cardio-metabolic diseases $[20,21]$.

Currently, although more research is needed to determine the best approach to management of NAFLD in women with PCOS, we propose that a more accurate, patient-centered, multidisciplinary approach to the management and treatment of NAFLD should be considered for young women with PCOS. A first-line therapeutic approach for NAFLD in women with PCOS should focus on lifestyle 
changes based on hypocaloric diet and increased physical activity [20,25]. A second-line therapeutic approach should consider lifestyle changes plus drug treatment. Metformin remains the drug of choice in PCOS [20,25]. Preliminary evidence also suggests some benefit of pioglitazone in the treatment of women with PCOS [20,44], as well as the use of either liraglutide or other glucagon-like peptide-1 receptor agonists for decreasing intra-hepatic fat content and visceral adipose tissue among women with PCOS who exhibit overweight/obesity $[45,46]$. However, to date, there is insufficient evidence to either support or refute the use of these newer drugs in women with PCOS and NAFLD. A better understanding of both the complex endocrine regulations of NAFLD and the interconnections linking PCOS with NAFLD will, in our expectations, also result in future advances in the pharmacological treatment of this increasingly prevalent and burdensome liver disease.

\section{Hypothyroidism}

\subsection{Diagnosis of Primary Hypothyroidism and Epidemiological Evidence Linking Hypothyroidism} with NAFLD

Hypothyroidism is a common endocrine disease characterized by thyroid hormone deficiency [47]. Classically, primary overt hypothyroidism is defined as serum thyroid-stimulating hormone (TSH) concentrations above the reference range and free thyroxine (FT4) concentrations below the reference range [47]. Subclinical hypothyroidism is, instead, defined by serum TSH concentrations above the reference range and FT4 concentrations within the normal range [47].

The rationale for investigating the association between hypothyroidism and NAFLD is based on two lines of evidence: firstly, the physiologic capacity of thyroid hormones to contrast the development of some features of the metabolic syndrome and, secondly, their direct effects on the liver [48-52]. However, the identification of NAFLD in a given patient with hypothyroidism does not necessarily imply that hypothyroidism is the cause of NAFLD in that specific patient [52]. On these grounds, it can be argued that not all observational studies and meta-analyses published so far clearly demonstrated a causal association between primary (subclinical and overt) hypothyroidism and risk of developing NAFLD, independent of coexisting cardio-metabolic risk factors (Table 1 [53-80]). For instance, in a large population-based cohort study, involving approximately 9500 Dutch euthyroid individuals from the Rotterdam Study, Bano et al. showed that both subclinical and overt hypothyroidism were significantly associated with an increased incidence of NAFLD, as detected with ultrasonography, even after adjustment for age, sex, BMI, alcohol intake, smoking, lipid profile, hypertension, and diabetes [70]. Similar findings were also reported by $\mathrm{Xu}$ et al. in a small prospective case-control study of 327 Chinese patients with subclinical hypothyroidism and 327 age-, sex-, and BMI-matched euthyroid controls [59]. Interestingly, Bril et al. found that, when serum TSH levels were normal, decreasing FT4 levels were significantly associated with increasing intra-hepatic fat content, as assessed by MRS, in a cohort of 232 United States euthyroid patients with type 2 diabetes [69]. However, the authors failed to find significant associations between thyroid function tests and histological features of NAFLD in a subset of patients submitted to liver biopsy [69]. By contrast, in a large longitudinal cohort study of as many as 18,500 South Korean individuals, Lee et al. showed that both subclinical and overt hypothyroidism were not significantly associated with an increased risk of incident NAFLD, as detected by ultrasonography, independent of multiple cardio-metabolic confounders [68]. At present, four published meta-analyses [77-80] further investigated the relationship between primary (subclinical and overt) hypothyroidism and risk of NAFLD. In the first meta-analysis, including 14 observational studies for a total of nearly 42,000 individuals, Jaruvongvanich et al. showed that NAFLD was not associated with subclinical (random-effects OR $0.63,95 \%$ CI $0.18-2.20$ ), overt (random-effects OR 1.37, 95\% CI 0.78-2.41), and unclassified hypothyroidism (random-effects OR 1.21, 95\% CI 0.91-1.61) [77]. In contrast, in the subsequent meta-analysis by He et al., including 13 observational studies for a total of approximately 37,000 individuals, both primary subclinical and overt hypothyroidism were associated with an increased risk of prevalent NAFLD, independent of several metabolic confounders (random-effects OR 1.52, 95\% CI 1.24-1.87) [78]. Again, in a recent meta-analysis of 12 cross-sectional and 
three longitudinal studies for a total of 44,140 individuals, both subclinical and overt hypothyroidism were independently associated with an increased risk of prevalent NAFLD (random-effects OR 1.42, 95\% CI 1.15-1.77) [79]. However, when the authors meta-analyzed the data from the three longitudinal studies, they found that subclinical hypothyroidism was not associated with an increased risk of incident NAFLD over a median follow-up of five years (random-effects hazard ratio $1.29,95 \% \mathrm{CI}$ 0.89-1.86) [79]. More recently, the meta-analysis by Guo et al., including 26 observational studies for a total of 61,548 individuals, documented that patients with NAFLD had significantly higher TSH levels than those without NAFLD, and that unclassified hypothyroidism was significantly associated with an increased risk of prevalent NAFLD [80].

With regard to the conflicting results found in observational studies [53-76] (Table 1), important differences in terms of study design, population characteristics, definition of hypothyroidism, and diagnosis of NAFLD are the most plausible explanations accounting for variable and inconsistent findings among the published studies. With regard to the meta-analyses [77-80], the divergent findings may be due to the use of different criteria for inclusion and exclusion of the studies, as well as to the presence of high statistical heterogeneity, which may indirectly reflect the aforementioned differences among the published observational studies.

Collectively, the currently available data [53-80] indicate that a significant and independent association between subclinical and overt hypothyroidism and risk of NAFLD remains to be conclusively proven. Large, prospective studies of well-characterized cohorts of patients (i.e., using a clear and consistent diagnostic definition of both hypothyroidism and NAFLD) are eagerly awaited.

\subsection{Putative Pathophysiological Mechanisms Linking Hypothyroidism with NAFLD}

To date, the biological mechanisms responsible for the development and the progression of NAFLD in individuals with hypothyroidism are incompletely understood. That said, the potential mechanisms linking hypothyroidism to NAFLD include metabolic syndrome, dyslipidemia, insulin resistance, oxidative stress, and direct action of TSH on the hepatocytes $[19,49,81]$.

In healthy individuals, the thyroid gland produces two hormones (i.e., thyroxine and triiodothyronine) which, acting through thyroid hormone receptors $\alpha$ and $\beta$, play a critical role in cell differentiation during development and help maintain thermogenic and metabolic homeostasis in adults [47].

Individuals with either subclinical or overt hypothyroidism often exhibit features of the metabolic syndrome, such as overweight/obesity, impaired fasting glucose, and atherogenic dyslipidemia [47]. In this context, we highlight that NAFLD typically occurs in close association with impaired glucose and lipid metabolism, as well as perturbed energy homeostasis [14,82], thereby justifying a close connection between hypothyroidism and NAFLD. In fact, as experimentally documented, overweight/obesity per se may blunt the effects of thyroid hormones on the liver, by profoundly affecting glucose and lipid metabolism and energy homeostasis $[19,49,81]$. In addition, hypothyroidism is also associated with atherogenic dyslipidemia (i.e., hypertriglyceridemia, increased plasma levels of low-density lipoprotein (LDL)-cholesterol and very low-density lipoprotein (VLDL)-cholesterol, reduced plasma levels of high-density lipoprotein (HDL)-cholesterol, and elevated apolipoprotein (apo)B lipoproteins) [82]. Hence, it is possible to speculate that hypothyroidism may further exacerbate NAFLD-associated dyslipidemia, which may also be worsened by insulin resistance $[19,81]$. 
Table 1. Observational studies and meta-analyses assessing the relationship between (subclinical and overt) hypothyroidism and risk of nonalcoholic fatty liver disease (NAFLD; ordered by publication year and study design).

\begin{tabular}{|c|c|c|c|c|c|}
\hline Ref. & Study Population & $\begin{array}{l}\text { Thyroid Function } \\
\text { Tests-Definition of } \\
\text { Hypothyroidism }\end{array}$ & $\begin{array}{l}\text { NAFLD Diagnosis; } \\
\text { Prevalence of } \\
\text { NAFLD }\end{array}$ & Adjustments & Main Findings \\
\hline \multicolumn{6}{|c|}{ Observational studies } \\
\hline$[53]$ & $\begin{array}{l}\text { Case-control study: } \\
174 \text { US patients with NASH and } \\
442 \text { age-, sex-, race-, and } \\
\text { BMI-matched controls }\end{array}$ & $\begin{array}{c}\text { Hypothyroidism was defined by } \\
\text { the self-reported use of } \\
\text { levothyroxine }\end{array}$ & Biopsy & $\begin{array}{l}\text { Diabetes, dyslipidemia, } \\
\text { hypertension }\end{array}$ & $\begin{array}{l}\text { Hypothyroidism was } \\
\text { independently associated with } \\
\text { an increased risk of NASH }\end{array}$ \\
\hline$[54]$ & $\begin{array}{c}\text { Cross-sectional study: } \\
\text { 878 Chinese elderly individuals }\end{array}$ & TSH, FT4, and FT3 & $\begin{array}{l}\text { USG; } 26 \% \text { with } \\
\text { NAFLD }\end{array}$ & $\begin{array}{c}\text { Age, BMI, waist circumference, } \\
\text { triglyceride, fasting glucose, } \\
\text { uric acid, creatinine }\end{array}$ & $\begin{array}{l}\text { FT4 levels were independently } \\
\text { associated with an increased } \\
\text { risk of NAFLD }\end{array}$ \\
\hline$[55]$ & $\begin{array}{l}\text { Cross-sectional study: } \\
1322 \text { Chinese individuals }\end{array}$ & $\begin{array}{l}\text { Hypothyroidism was defined as } \\
\text { TSH levels }>2.5 \mathrm{mIU} / \mathrm{L}\end{array}$ & $\begin{array}{l}\text { USG; } 25 \% \text { with } \\
\text { NAFLD }\end{array}$ & $\begin{array}{l}\text { Age, sex, BMI, body fat, } \\
\text { triglycerides, systolic blood } \\
\text { pressure, diastolic blood } \\
\text { pressure, fasting glucose }\end{array}$ & $\begin{array}{l}\text { Hypothyroidism was not } \\
\text { independently associated with } \\
\text { an increased risk of NAFLD }\end{array}$ \\
\hline$[56]$ & $\begin{array}{c}\text { Population-based study } \\
\text { (Study of Health in Pomerania): } \\
3661 \text { German individuals }\end{array}$ & $\begin{array}{c}\text { Subclinical hypothyroidism was } \\
\text { defined as TSH }>3 \mathrm{mIU} / \mathrm{L} \text { and } \\
\text { normal FT4; overt hypo thyroidism } \\
\text { was defined as TSH }>3 \mathrm{mIU} / \mathrm{L} \text { and } \\
\text { FT4 }<7 \mathrm{pmol} / \mathrm{L}\end{array}$ & $\begin{array}{l}\text { USG; } 16 \% \text { with } \\
\text { NAFLD }\end{array}$ & $\begin{array}{l}\text { Age, waist circumference, } \\
\text { physical activity, alcohol intake, } \\
\text { food intake pattern }\end{array}$ & $\begin{array}{l}\text { Hypothyroidism was not } \\
\text { independently associated with } \\
\text { an increased risk of NAFLD. } \\
\text { Contrariwise, serum FT4 levels } \\
\text { were inversely associated with } \\
\text { NAFLD }\end{array}$ \\
\hline [57] & $\begin{array}{l}\text { Case-control study: } 246 \text { US } \\
\text { patients with biopsy-proven } \\
\text { NAFLD and } 430 \text { age-, sex-, } \\
\text { race-, and BMI-matched } \\
\text { controls }\end{array}$ & $\begin{array}{c}\text { Hypothyroidism was defined by } \\
\text { the self-reported use of } \\
\text { levothyroxine }\end{array}$ & Biopsy & Alcohol use & $\begin{array}{l}\text { Hypothyroidism was } \\
\text { independently associated with } \\
\text { an increased risk of NAFLD }\end{array}$ \\
\hline$[58]$ & $\begin{array}{l}\text { Cross-sectional study: } \\
4648 \text { South Korean adults }\end{array}$ & $\begin{array}{c}\text { Subclinical hypothyroidism was } \\
\text { defined as TSH } \geq 4.1 \text { mIU/L and } \\
\text { normal FT4; overt hypothyroidism } \\
\text { was defined as FT4 }<0.7 \mathrm{ng} / \mathrm{dL}\end{array}$ & $\begin{array}{l}\text { USG; } 25 \% \text { with } \\
\text { NAFLD }\end{array}$ & $\begin{array}{l}\text { Age, sex, BMI, waist } \\
\text { circumference, lipids } \\
\text { hypertension, diabetes }\end{array}$ & $\begin{array}{c}\text { Subclinical and overt } \\
\text { hypothyroidism were } \\
\text { independently associated with } \\
\text { an increased risk of NAFLD }\end{array}$ \\
\hline
\end{tabular}


Table 1. Cont.

\begin{tabular}{|c|c|c|c|c|c|}
\hline Ref. & Study Population & $\begin{array}{l}\text { Thyroid Function } \\
\text { Tests-Definition of } \\
\text { Hypothyroidism }\end{array}$ & $\begin{array}{l}\text { NAFLD Diagnosis; } \\
\text { Prevalence of } \\
\text { NAFLD }\end{array}$ & Adjustments & Main Findings \\
\hline [59] & $\begin{array}{c}\text { Prospective case-control study: } \\
327 \text { Chinese patients with } \\
\text { subclinical hypothyroidism and } \\
327 \text { age-, sex-, and } \\
\text { BMI-matched euthyroid } \\
\text { controls }\end{array}$ & $\begin{array}{c}\text { Subclinical hypothyroidism was } \\
\text { defined as TSH } \geq 4.5 \mathrm{mIU} / \mathrm{L} \text { and } \\
\text { normal FT4 levels }\end{array}$ & $\begin{array}{l}\text { USG; } 15 \% \text { of } \\
\text { individuals developed } \\
\text { NAFLD over a median } \\
\text { follow-up of } \sim 5 \text { years }\end{array}$ & $\begin{array}{l}\text { Waist circumference, systolic } \\
\text { blood pressure, diastolic blood } \\
\text { pressure, lipids, fasting glucose }\end{array}$ & $\begin{array}{l}\text { Subclinical hypothyroidism } \\
\text { was independently associated } \\
\text { with an increased risk of } \\
\text { NAFLD during the follow-up }\end{array}$ \\
\hline$[60]$ & $\begin{array}{l}\text { Cross-sectional study: } 69 \text { Italian } \\
\text { euthyroid patients with } \\
\text { biopsy-proven NAFLD }\end{array}$ & TSH & $\begin{array}{c}\text { Biopsy; } 44 \text { patients } \\
\text { had NASH, whereas } \\
25 \text { patients had only } \\
\text { steatosis }\end{array}$ & Age, sex, BMI, HOMA & $\begin{array}{l}\text { TSH levels were independently } \\
\text { and positively associated with } \\
\text { an increased risk of NASH }\end{array}$ \\
\hline$[61]$ & $\begin{array}{l}\text { Cross-sectional study: } \\
832 \text { Iranian healthy individuals }\end{array}$ & $\begin{array}{c}\text { Subclinical hypothyroidism was } \\
\text { defined as TSH }>5.2 \mathrm{mIU} / \mathrm{L} \text { and } \\
\text { normal FT4 levels; overt } \\
\text { hypothyroidism was defined as } \\
\text { TSH }>5.2 \mathrm{mIU} / \mathrm{L} \text { and } \\
\text { FT4 }<11.5 \mathrm{pmol} / \mathrm{L}\end{array}$ & $\begin{array}{l}\text { USG; } 15 \% \text { with } \\
\text { NAFLD }\end{array}$ & None & $\begin{array}{c}\text { Subclinical and overt } \\
\text { hypothyroidism were not } \\
\text { independently associated with } \\
\text { an increased risk of NAFLD }\end{array}$ \\
\hline$[62]$ & $\begin{array}{c}\text { Cross-sectional study: } \\
753 \text { Mexican adults from the } \\
\text { Genetics of Atherosclerotic } \\
\text { Disease study }\end{array}$ & $\begin{array}{c}\text { Subclinical hypothyroidism was } \\
\text { defined as TSH }>4.5 \mathrm{mIU} / \mathrm{L} \text { and } \\
\text { normal FT4 levels }\end{array}$ & $\begin{array}{l}\text { Computed } \\
\text { tomography; } 31 \% \\
\text { with NAFLD }\end{array}$ & None & $\begin{array}{l}\text { Subclinical hypothyroidism } \\
\text { was not independently } \\
\text { associated with an increased } \\
\text { risk of NAFLD }\end{array}$ \\
\hline$[63]$ & $\begin{array}{l}\text { Cross-sectional study: } \\
739 \text { Chinese euthyroid } \\
\text { individuals }\end{array}$ & TSH, FT4 & $\begin{array}{l}\text { USG; } 26 \% \text { with } \\
\text { NAFLD }\end{array}$ & $\begin{array}{l}\text { Age, sex, BMI, smoking status, } \\
\text { systolic blood pressure, } \\
\text { diastolic blood pressure, } \\
\text { lipids, FT3 }\end{array}$ & $\begin{array}{l}\text { TSH and FT4 levels were } \\
\text { independently associated with } \\
\text { an increased risk of NAFLD }\end{array}$ \\
\hline$[64]$ & $\begin{array}{l}\text { Cross-sectional study: } \\
2576 \text { euthyroid South Koreans }\end{array}$ & TSH, FT4, FT3 & $\begin{array}{l}\text { USG; } 38 \% \text { with } \\
\text { NAFLD }\end{array}$ & $\begin{array}{l}\text { Age, sex, smoking status, } \\
\text { hypertension, fasting glucose, } \\
\text { lipids, creatinine, uric acid }\end{array}$ & $\begin{array}{c}\text { FT3 levels, but not TSH and FT4 } \\
\text { levels, were independently } \\
\text { associated with an increased } \\
\text { risk of NAFLD }\end{array}$ \\
\hline [65] & $\begin{array}{l}\text { Cross-sectional study: } \\
1154 \text { Chinese with chronic } \\
\text { hepatitis B }\end{array}$ & $\begin{array}{c}\text { Subclinical hypothyroidism was } \\
\text { defined as serum TSH }>5.3 \mathrm{mUI} / \mathrm{L} \\
\text { and normal FT4 levels, whereas } \\
\text { overt hypothyroidism was defined } \\
\text { as serum FT4 level }<7.9 \mathrm{pmol} / \mathrm{L} \text { and } \\
\text { TSH }>5.3 \mathrm{mIU} / \mathrm{L}\end{array}$ & $\begin{array}{l}\text { Biopsy; } 23 \% \text { with } \\
\text { NAFLD }\end{array}$ & Age, sex & $\begin{array}{l}\text { TSH levels were independently } \\
\text { and positively associated with } \\
\text { an increased risk of NAFLD }\end{array}$ \\
\hline
\end{tabular}


Table 1. Cont.

\begin{tabular}{|c|c|c|c|c|c|}
\hline Ref. & Study Population & $\begin{array}{l}\text { Thyroid Function } \\
\text { Tests-Definition of } \\
\text { Hypothyroidism }\end{array}$ & $\begin{array}{l}\text { NAFLD Diagnosis; } \\
\text { Prevalence of } \\
\text { NAFLD }\end{array}$ & Adjustments & Main Findings \\
\hline$[66]$ & $\begin{array}{c}\text { Case-control study: } \\
500 \text { biopsy-proven NAFLD } \\
\text { Indians and } 300 \text { age-, sex-, and } \\
\text { BMI-matched controls }\end{array}$ & $\begin{array}{c}\text { Hypothyroidism was defined by } \\
\text { the self-reported use of } \\
\text { levothyroxine }\end{array}$ & Biopsy & Age, sex, BMI, transaminases & $\begin{array}{l}\text { Hypothyroidism was } \\
\text { independently associated with } \\
\text { an increased risk of NAFLD }\end{array}$ \\
\hline$[67]$ & $\begin{array}{l}\text { Population-based study: } \\
1276 \text { Germans }\end{array}$ & $\begin{array}{l}\text { Subclinical hypothyroidism was } \\
\text { defined as TSH } \geq 3.4 \mathrm{mIU} / \mathrm{L} \text { and } \\
\text { normal FT4 levels; overt } \\
\text { hypothyroidism was defined as } \\
\text { total T4 levels }<12.8 \mathrm{pmol} / \mathrm{L} \text { and } \\
\text { TSH levels } \geq 3.4 \mathrm{mIU} / \mathrm{L}\end{array}$ & $\begin{array}{l}\text { USG; } 25 \% \text { with } \\
\text { NAFLD }\end{array}$ & $\begin{array}{l}\text { Age, sex, BMI, waist } \\
\text { circumference }\end{array}$ & $\begin{array}{c}\text { Subclinical and overt } \\
\text { hypothyroidism were not } \\
\text { independently associated with } \\
\text { an increased risk of NAFLD }\end{array}$ \\
\hline$[68]$ & $\begin{array}{l}\text { Longitudinal study: } \\
\text { 18,544 healthy South Koreans } \\
\text { NAFLD-free at baseline }\end{array}$ & $\begin{array}{c}\text { Subclinical hypothyroidism was } \\
\text { defined as TSH }>4.2 \text { mIU/L normal } \\
\text { FT4 levels; overt hypothyroidism } \\
\text { was defined as TSH }>4.2 \text { mIU/L } \\
\text { and FT4 }<0.9 \mathrm{ng} / \mathrm{dL}\end{array}$ & $\begin{array}{c}\text { USG; } 2348 \text { individuals } \\
\text { developed incident } \\
\text { NAFLD during a } \\
\text { mean follow-up of } \\
4 \text { years }\end{array}$ & $\begin{array}{l}\text { Age, sex, BMI, metabolic } \\
\text { syndrome }\end{array}$ & $\begin{array}{c}\text { Subclinical and overt } \\
\text { hypothyroidism were not } \\
\text { independently associated with } \\
\text { an increased risk of NAFLD }\end{array}$ \\
\hline [69] & $\begin{array}{l}\text { Cross-sectional study: } 232 \text { USA } \\
\text { euthyroid patients with T2D }\end{array}$ & FT4 & $\begin{array}{l}\text { MRS; liver biopsy was } \\
\text { performed in patients } \\
\text { with a diagnosis of } \\
\text { NAFLD; } 63 \% \text { with } \\
\text { NAFLD }\end{array}$ & Age, BMI, hemoglobin A1c & $\begin{array}{l}\text { FT4 levels were significantly } \\
\text { associated with hepatic } \\
\text { triglyceride. However, no } \\
\text { associations between thyroid } \\
\text { function tests and liver } \\
\text { histological parameters (such as } \\
\text { inflammation, hepatocyte } \\
\text { ballooning, and advanced } \\
\text { fibrosis) were observed }\end{array}$ \\
\hline$[70]$ & $\begin{array}{l}\text { A population-based, } \\
\text { prospective cohort study } \\
\text { (the Rotterdam study): } \\
9419 \text { Dutch euthyroid } \\
\text { individuals }\end{array}$ & $\begin{array}{c}\text { Subclinical hypothyroidism was } \\
\text { defined as serum TSH levels } \\
>4.0 \mathrm{mIU} / \mathrm{L} \text { and normal FT4; overt } \\
\text { hypothyroidism was defined as } \\
\text { serum TSH }>4.0 \mathrm{mIU} / \mathrm{L} \text { and FT4 } \\
\text { levels }<0.8 \mathrm{ng} / \mathrm{dL}\end{array}$ & $\begin{array}{c}\text { Fatty liver index at } \\
\text { baseline; USG and } \\
\text { Fibroscan }{ }_{\circledast} \text { at } \\
\text { follow-up; } 13 \% \text { of } \\
\text { participants } \\
\text { developed incident } \\
\text { NAFLD over a median } \\
\text { follow-up of } 10 \text { years }\end{array}$ & $\begin{array}{l}\text { Age, sex, BMI, alcohol intake, } \\
\text { smoking status, follow-up time, } \\
\text { use of lipid-lowering agents, } \\
\text { lipids, hypertension, diabetes }\end{array}$ & $\begin{array}{l}\text { Compared to euthyroidism, any } \\
\text { form of hypothyroidism was } \\
\text { associated with an increased } \\
\text { risk of NAFLD. Moreover, } \\
\text { subclinical and overt } \\
\text { hypothyroidism were } \\
\text { associated with an increased } \\
\text { risk of liver fibrosis as detected } \\
\text { by Fibroscan } \\
\mathbb{R}\end{array}$ \\
\hline
\end{tabular}


Table 1. Cont.

\begin{tabular}{|c|c|c|c|c|c|}
\hline Ref. & Study Population & $\begin{array}{l}\text { Thyroid Function } \\
\text { Tests-Definition of } \\
\text { Hypothyroidism }\end{array}$ & $\begin{array}{l}\text { NAFLD Diagnosis; } \\
\text { Prevalence of } \\
\text { NAFLD }\end{array}$ & Adjustments & Main Findings \\
\hline [71] & $\begin{array}{l}\text { Cross-sectional study: } \\
115 \text { Turkish individuals }\end{array}$ & FT3/FT4 ratio & $\begin{array}{l}\text { USG; } 60 \% \text { with } \\
\text { NAFLD }\end{array}$ & $\begin{array}{l}\text { Waist circumference, } \\
\text { lipids, uric acid, HOMA }\end{array}$ & $\begin{array}{c}\text { FT3/FT4 ratio was } \\
\text { independently associated with } \\
\text { an increased risk of NAFLD }\end{array}$ \\
\hline [72] & $\begin{array}{c}\text { Population-based study } \\
\text { (Lifelines Cohort Study): } \\
\text { 20,289 Dutch euthyroid } \\
\text { individuals }\end{array}$ & TSH, FT4, FT3 & $\begin{array}{c}\text { FLI }(\geq 60) ; 21 \% \text { with } \\
\text { NAFLD }\end{array}$ & Age, sex & $\begin{array}{c}\text { FLI } \geq 60 \text { was independently } \\
\text { associated with higher FT3 and } \\
\text { lower FT4 levels }\end{array}$ \\
\hline [73] & $\begin{array}{l}\text { Cross-sectional study: } \\
580 \text { Filipino adults }\end{array}$ & $\begin{array}{c}\mathrm{TSH}>4.5 \mathrm{mIU} / \mathrm{L} \text { without previous } \\
\text { history of thyroid disease }\end{array}$ & $\begin{array}{l}\text { USG; } 48 \% \text { with } \\
\text { NAFLD }\end{array}$ & None & $\begin{array}{l}\text { NAFLD was not independently } \\
\text { associated with TSH levels }\end{array}$ \\
\hline [74] & $\begin{array}{l}\text { Case-control study } 100 \text { Indian } \\
\text { adult non-obese hypothyroid } \\
\text { patients and } 100 \text { age-, sex-, and } \\
\text { BMI-matched euthyroid } \\
\text { controls }\end{array}$ & $\begin{array}{c}\text { Subclinical hypothyroidism was } \\
\text { defined as serum TSH levels } \\
\geq 4.1 \mathrm{mIU} / \mathrm{L} \text { and normal FT4 levels, } \\
\text { whereas overt hypothyroidism was } \\
\text { defined as serum TSH levels } \\
\geq 4.1 \mathrm{mIU} / \mathrm{L} \text { and FT4 levels } \\
<0.7 \mathrm{ng} / \mathrm{dL}\end{array}$ & $\begin{array}{l}\text { USG; } 42 \% \text { with } \\
\text { NAFLD }\end{array}$ & None & $\begin{array}{l}\text { NAFLD was diagnosed in } \\
30 \text { patients with hypothyroid } \\
\text { and in } 12 \text { controls }\end{array}$ \\
\hline [75] & $\begin{array}{l}\text { Cross-sectional study: } \\
425 \text { South Koreans with } \\
\text { biopsy-proven NAFLD }\end{array}$ & $\begin{array}{c}\text { Subclinical hypothyroidism was } \\
\text { defined as serum TSH }>4.5 \mathrm{mIU} / \mathrm{L} \\
\text { and normal FT4 }\end{array}$ & Biopsy & $\begin{array}{c}\text { Age, sex, BMI, smoking status, } \\
\text { hypertension, diabetes, lipids, } \\
\text { visceral adipose tissue area, } \\
\text { HOMA-IR }\end{array}$ & $\begin{array}{c}\text { Subclinical hypothyroidism } \\
\text { was independently associated } \\
\text { with an increased risk of NASH } \\
\text { and advanced fibrosis }\end{array}$ \\
\hline [76] & $\begin{array}{l}\text { Population-based study: } \\
\text { 3452 Koreans from Korea } \\
\text { National Health and Nutrition } \\
\text { Examination Survey } 2013 \\
\text { to } 2015\end{array}$ & $\begin{array}{l}\text { Subclinical hypothyroidism was } \\
\text { defined as a serum TSH levels } \\
>6.7 \mathrm{mIU} / \mathrm{L} \text { with serum FT4 within } \\
\text { a normal range }\end{array}$ & $\begin{array}{l}\text { Hepatic steatosis } \\
\quad \text { index }(\geq 36)\end{array}$ & $\begin{array}{l}\text { Age, smoking status, physical } \\
\text { activity, income, MetS, waist } \\
\text { circumference, lipids, systolic } \\
\text { blood pressure, diastolic blood } \\
\text { pressure, fasting glucose, urine } \\
\text { iodine, thyroid peroxidase } \\
\text { antibodies }\end{array}$ & $\begin{array}{l}\text { Subclinical hypothyroidism } \\
\text { was independently associated } \\
\text { with an increased risk of } \\
\text { NAFLD in males, but not in } \\
\text { females }\end{array}$ \\
\hline
\end{tabular}


Table 1. Cont.

\begin{tabular}{|c|c|c|c|c|c|}
\hline Ref. & Study Population & $\begin{array}{l}\text { Thyroid Function } \\
\text { Tests-Definition of } \\
\text { Hypothyroidism }\end{array}$ & $\begin{array}{l}\text { NAFLD Diagnosis; } \\
\text { Prevalence of } \\
\text { NAFLD }\end{array}$ & Adjustments & Main Findings \\
\hline \multicolumn{6}{|c|}{ Meta-analyses } \\
\hline [77] & $\begin{array}{l}14 \text { observational studies for a } \\
\text { total of } 42,143 \text { individuals }\end{array}$ & $\begin{array}{c}\text { Self-reported history of } \\
\text { hypothyroidism with use of } \\
\text { levothyroxine replacement therapy } \\
\text { or by presence of abnormal thyroid } \\
\text { function tests }\end{array}$ & Imaging and biopsy & $\begin{array}{l}\text { Multiple demographic and } \\
\text { clinical variables }\end{array}$ & $\begin{array}{l}\text { NAFLD was not independently } \\
\text { associated with } \\
\text { hypothyroidism }\end{array}$ \\
\hline$[78]$ & $\begin{array}{l}13 \text { observational studies for a } \\
\text { total of } 37,194 \text { individuals }\end{array}$ & $\begin{array}{c}\text { Self-reported history of } \\
\text { hypothyroidism with use of } \\
\text { levothyroxine replacement therapy } \\
\text { or by presence of abnormal thyroid } \\
\text { function tests }\end{array}$ & $\begin{array}{l}\text { Liver enzymes, } \\
\text { imaging, and biopsy }\end{array}$ & $\begin{array}{l}\text { Multiple demographic and } \\
\text { clinical variables }\end{array}$ & $\begin{array}{l}\text { Hypothyroidism was } \\
\text { independently associated with } \\
\text { an increased risk of NAFLD }\end{array}$ \\
\hline$[79]$ & $\begin{array}{l}12 \text { cross-sectional and } \\
3 \text { longitudinal studies for a total } \\
\text { of } 44,140 \text { individuals }\end{array}$ & $\begin{array}{c}\text { Self-reported history of } \\
\text { hypothyroidism with use of } \\
\text { levothyroxine replacement therapy } \\
\text { or by presence of abnormal thyroid } \\
\text { function tests }\end{array}$ & Imaging and biopsy & $\begin{array}{l}\text { Multiple demographic and } \\
\text { clinical variables }\end{array}$ & $\begin{array}{c}\text { Hypothyroidism was } \\
\text { independently associated with } \\
\text { an increased risk of prevalent } \\
\text { NAFLD. Meta-analysis of data } \\
\text { from } 3 \text { longitudinal studies } \\
\text { documented that subclinical } \\
\text { hypothyroidism was not } \\
\text { independently associated with } \\
\text { an increased risk of incident } \\
\text { over a median follow-up of } \\
5 \text { years }\end{array}$ \\
\hline [80] & $\begin{array}{l}26 \text { observational studies for a } \\
\text { total of } 61,548 \text { individuals }\end{array}$ & $\begin{array}{l}\text { Self-reported history of } \\
\text { hypothyroidism with use of } \\
\text { levothyroxine replacement therapy } \\
\text { or by presence of abnormal thyroid } \\
\text { function tests }\end{array}$ & $\begin{array}{l}\text { Imaging, FLI, and } \\
\text { biopsy }\end{array}$ & $\begin{array}{l}\text { Multiple demographic and } \\
\text { clinical variables }\end{array}$ & $\begin{array}{l}\text { NAFLD patients had } \\
\text { significantly higher TSH levels } \\
\text { compared to controls. In } \\
\text { addition, hypothyroidism was } \\
\text { significantly associated with the } \\
\text { risk of NAFLD }\end{array}$ \\
\hline
\end{tabular}

Abbreviations: BMI, body mass index; FLI, fatty liver index; FT3, free triiodothyronine; FT4, free thyroxine; HOMA, homeostatic model assessment; IR, insulin resistance; NAFLD, nonalcoholic fatty liver disease; MetS, metabolic syndrome; MRS, magnetic resonance spectroscopy; NASH, nonalcoholic steatohepatitis; T2D, type 2 diabetes; TSH, thyroid-stimulating hormone; USA, United States of America, USG, ultrasonography. 
Hypothyroidism is often associated with insulin resistance [19,51,81]. Preliminary evidence suggests that elevated levels of certain adipocytokines [e.g., leptin, visfatin, tumor necrosis factor- $\alpha$ (TNF- $\alpha$ ), and interleukin-1] and increased oxidative stress, occurring during some conditions of hypothyroidism, may concur with the development of insulin resistance $[19,49,81]$. Alterations in specific cytokine levels and markers of oxidative stress, including reactive oxygen species (ROS) and markers of lipid peroxidation, are shared features which are often observed in patients with hypothyroidism [19,81], as well as in those with NAFLD [82], thus representing a further potential pathophysiological mechanism underpinning the association between hypothyroidism and NAFLD.

In addition to the adverse effects of decreased serum thyroid hormones on hepatic glucose and lipid metabolism, and potentially explaining the epidemiological finding that also subclinical hypothyroidism may be sufficient to increase the risk of NAFLD, elevated serum TSH per se may promote the development of NAFLD by stimulating hepatic de novo lipogenesis $[19,49,81]$. The biological activity of TSH is mediated by its specific interaction with the thyrotropin receptor, which is not only expressed on the membrane of thyroid follicular cells, but also in several extra-thyroidal tissues and cells, including the hepatocytes [81]. Interestingly, increasing TSH concentrations may directly induce NAFLD by increasing the intra-hepatocytic triglyceride content $[19,81,83]$. The molecular mechanism underlying the hepatic steatogenesis induced by increasing TSH levels include activation of hepatic sterol regulatory element-binding transcription factor 1 (SREBP-1c) via the cyclic AMP (cAMP)/protein kinase A (PKA)/peroxisome proliferator-activated receptor- $\alpha$ (PPAR $\alpha)$ pathway associated with decreased AMP-activated protein kinase (AMPK), which further increases the expression of genes, finally leading to enhanced steatogenesis $[49,81,84]$.

\subsection{Diagnosis and Management of NAFLD in Patients with Hypothyroidism}

Given that hypothyroidism is often associated with features of the metabolic syndrome [19] and that NAFLD is bi-directionally and mutually associated with the metabolic syndrome [79], a strong consideration for NAFLD should be given to patients with hypothyroidism, especially whenever they are overweight or obese [62,79]. However, we highlight that this topic is not covered by guidelines issued by scientific societies; therefore, the aforementioned statement, which is strongly supported by epidemiological evidence, mirrors the opinions of the authors.

Replacement therapy with levothyroxine, the standard treatment of hypothyroidism, is associated with a significant decrease in BMI and serum lipids [47]. To date, there is scarce information on whether treatment of hypothyroidism with levothyroxine is also able to improve NAFLD. In a post hoc analysis of a randomized controlled trial, involving 360 patients with subclinical hypothyroidism, the treatment with levothyroxine proved beneficial on serum liver enzyme levels and ultrasound-diagnosed NAFLD after a 15-month period [85]. In a recent phase IIb single-arm trial, involving 20 euthyroid patients with type 2 diabetes and NAFLD, the administration of low-dose levothyroxine for 16 weeks was associated with a significant reduction of the intra-hepatic fat content, as assessed with MRS [86]. A small multicenter, double-blind, randomized, placebo-controlled phase 2 trial is ongoing to evaluate the efficacy and safety of a highly selective liver-directed, thyroid hormone receptor- $\beta$ agonist, namely MGL-3196, in patients with biopsy-proven NASH [79]. However, at present, all these data are heavily insufficient to recommend the prescription of levothyroxine in (a subset of) patients with primary NAFLD. Therefore, additional clinical trials with liver histology endpoints are required to firmly establish the potential benefits of the use of either levothyroxine or thyroid hormone receptor agonists in patients with primary NAFLD.

Finally, specific lifestyle modifications (together with replacement therapy with levothyroxine) are strongly recommended for patients with hypothyroidism, NAFLD, and metabolic syndrome features. By contrast, the use of insulin sensitizers and antioxidants was never studied in this subtype of patients and, to date, no available guideline regarding NAFLD or hypothyroidism addresses this emerging aspect. 


\section{Hypogonadism}

\subsection{Definition and Epidemiological Grounds}

Irrespective of its variable underlying pathophysiological mechanisms, hypogonadism defines the presence of reduced sex hormone concentrations in either sex [87]. Thus, while all types of hypogonadism invariably result in low sex hormone levels, the clinical scenario is highly variable as a function of the specific etiology (Table 2) [87]. Despite such a tremendous phenotypic variability, the development and progression of NAFLD are common denominators of hypogonadism, independent of sex and etiology.

Table 2. Main causes of hypogonadism (modified from Mintziori et al. [87]).

\begin{tabular}{c} 
Primary (hypergonadotropic) \\
Congenital anatomical abnormalities of the gonads \\
Castration \\
Specific syndromes (e.g., Turner's syndrome; Alstrom's syndrome; Kallmann syndrome) \\
Drugs (e.g., antiandrogens, antiestrogens, chemotherapy) \\
Radiation \\
Hemochromatosis \\
Autoimmune \\
\hline Secondary to pituitary/hypothalamic failure (hypogonadotropic) \\
Congenital \\
Tumor \\
Trauma \\
Radiation \\
Functional \\
\hline
\end{tabular}

As shown in Table 3, a growing number of studies support a strong and bi-directional association between NAFLD and hypogonadism in both men and women [88-102]. 
Table 3. Epidemiological evidence supporting the notion that patients with hypogonadism are at higher risk of NAFLD.

\begin{tabular}{|c|c|c|c|}
\hline Ref. & Study Characteristics & Diagnosis of NAFLD & Main Findings \\
\hline \multicolumn{4}{|c|}{ Hypogonadism in men } \\
\hline [88] & $\begin{array}{l}\text { A cohort of } 117 \text { hypogonadic men ( } 34-69 \text { years), who were } \\
\text { treated with HRT (testosterone undecanoate for } 1 \text { year) }\end{array}$ & $\mathrm{ALT}, \mathrm{AST}$, and CRP & $\begin{array}{c}\text { HRT was associated with a significant reduction in adiposity measures, lipid } \\
\text { profile, and rate of individuals who met the criteria of the MetS. Steatosis } \\
\text { was strongly associated with all components of the MetS and RLE, which } \\
\text { were associated with higher plasma CRP concentrations, significantly } \\
\text { decreased following 1-year HRT }\end{array}$ \\
\hline [89] & $\begin{array}{l}1944 \text { non-drinking men submitted to repeated liver } \\
\text { ultrasonography over a median } 4.2 \text {-year period, with } \\
\text { available baseline serum TT level were evaluated }\end{array}$ & Ultrasonography & $\begin{array}{c}\text { Baseline levels of TT were significantly lower in NAFLD individuals in } \\
\text { cross-sectional analyses. However, TT level was not independently } \\
\text { associated with either development or regression of NAFLD during } \\
\text { follow-up }\end{array}$ \\
\hline [90] & $\begin{array}{l}\text { Retrospective study comparing } 75 \text { Chinese IHH men } \\
\text { (mean age } 21.4 \pm 3.8 \text { years, range } 17-30 \text { years) to } 135 \text { age- } \\
\text { and sex-matched healthy controls }\end{array}$ & Ultrasonography & $\begin{array}{l}\text { Compared to healthy controls, IHH men had higher serum ACTH levels, } \\
\text { lower cortisol levels, deranged glycolipidic profile and a higher prevalence } \\
\text { of NAFLD. NAFLD was independently associated with ACTH levels }\end{array}$ \\
\hline [91] & $\begin{array}{l}55 \text { consecutive men with chronic SCI admitted to a } \\
\text { rehabilitation program were submitted to } \\
\text { clinical/biochemical evaluations and liver ultrasonography }\end{array}$ & Ultrasonography & $\begin{array}{l}\text { NAFLD was diagnosed in } 49 \% \text { of cases. TT and FT levels were } \\
\text { independently associated with NAFLD; the risk of NAFLD increased by } 1 \% \\
\text { for each decrement of } 1 \mathrm{ng} / \mathrm{dL} \text { of TT and of } 3 \% \text { for each decrement of } \\
\qquad 1 \mathrm{pg} / \mathrm{mL} \text { of FT }\end{array}$ \\
\hline [92] & $\begin{array}{l}\text { Out of } 380,669 \text { men with histologically proven prostate } \\
\text { cancer, } 31,117 \text { elderly men who received ADT were } \\
\text { identified by using a representative cancer registry. } \\
\text { Individuals with metastatic disease, pre-existent MetS, } \\
\text { diabetes, preexisting liver disease, or a history of } \\
\text { alcoholism/ alcohol related disorders were excluded }\end{array}$ & $\begin{array}{l}\text { Diagnostic and procedural codes } \\
\text { from physician office or inpatient visits }\end{array}$ & $\begin{array}{l}\text { Elderly men submitted to ADT were more likely to be diagnosed with } \\
\text { NAFLD, cirrhosis, liver necrosis, and any liver disease }\end{array}$ \\
\hline \multicolumn{4}{|c|}{ Hypogonadism in women } \\
\hline [93] & $\begin{array}{l}\text { Retrospective analysis of serum liver enzymes in } 80 \text { women } \\
\text { with TS, followed by a prospective study in } 20 \text { women with } \\
\text { TS following } 3 \text { months on-and-off HRT }\end{array}$ & GGT, AST, and ALP & $\begin{array}{l}44 \% \text { of women with TS had RLE. HRT resulted in a significant reduction in } \\
\text { serum liver enzymes without improving serum protein concentrations }\end{array}$ \\
\hline [94] & $\begin{array}{c}\text { Prospective, double-blind, RCT vs. placebo recruiting } \\
5408 \text { women who underwent hysterectomies and enrolled } \\
\text { into the multicentric Italian tamoxifen } \\
\text { chemoprevention trial }\end{array}$ & $\begin{array}{l}\text { NAFLD was suspected based on de novo } \\
\text { incident chronic unexplained } \\
\text { hyper-transaminasemia }(\times 1.5 \text { n.v.) over } \\
\text { a 6-month period, in the absence of } \\
\text { competing etiologies and confirmed with } \\
\text { ultrasonography. NAFLD women } \\
\text { defined as above were offered } \\
\text { confirmative liver biopsy }\end{array}$ & $\begin{array}{l}52 \text { out of } 64 \text { women who met the predefined criteria in the course of } \\
\text { follow-up developed suspected US-confirmed NAFLD: } 34 \text { on tamoxifen vs. } \\
18 \text { on placebo, HR }=2.0 \text { ( } 95 \% \text { CI } 1.1-3.5 ; p=0.04) \text {. Further to tamoxifen, } \\
\text { overweight (HR } 2.4,95 \% \text { CI 1.2-4.8), obesity (HR 3.6, } 95 \% \text { CI 1.7-7.6), } \\
\text { hypercholesterolemia (HR 3.4, 9\%\% CI 1.4-7.8), and hypertension (HR 2.0, } \\
95 \% \text { CI 1.0-3.8) were associated with increased risk of incident NAFLD. Out } \\
\text { of } 20 \text { women submitted to LB, } 15 \text { had mild-to-moderate NASH } \\
\text { (12 tamoxifen vs. } 3 \text { placebo), and } 5 \text { had simple steatosis ( } 1 \text { tamoxifen vs. } \\
4 \text { placebo). None developed cirrhosis over a mean } 8.7 \text {-year follow-up }\end{array}$ \\
\hline
\end{tabular}


Table 3. Cont

\begin{tabular}{|c|c|c|c|}
\hline Ref. & Study Characteristics & Diagnosis of NAFLD & Main Findings \\
\hline [95] & $\begin{array}{l}50 \text { women with T2D entered a double-blind, RCT of HRT } \\
\text { vs. placebo }\end{array}$ & AST, ALT, GGT, and ALP & $\begin{array}{l}\text { Compared to those randomized to placebo, women randomized and } \\
\text { compliant to HRT }(n=19) \text { had significant reductions in serum liver enzymes }\end{array}$ \\
\hline [96] & $\begin{array}{l}\text { Serum liver enzymes were assessed in } 169 \text { women (14 with } \\
\text { TS and } 11 \text { controls with hypogonadism) on HRT with oral } \\
\text { E2 }\end{array}$ & GGT, ALT, ALP, albumin, and bilirubin & $\begin{array}{l}\text { The prevalence and incidence rates of RLE among women with TS were } 91 \% \\
\text { and } 2.1 \% \text { per year, respectively. RLE were associated with total cholesterol } \\
\text { and BMI, and reversed by increasing doses of HRT }\end{array}$ \\
\hline$[97]$ & $\begin{array}{l}218 \text { women with TS (mean age } 33 \pm 13 \text {, range } 16-71 \text { years) } \\
\text { from outpatient clinics at Swedish university hospitals. }\end{array}$ & $\begin{array}{l}\text { AST, ALT, ALP, GGT, serology for viral } \\
\text { hepatitis and liver-specific } \\
\text { auto-antibodies }\end{array}$ & $\begin{array}{c}36 \% \text { of TS women had one or more RLE; the most prevalent was serum GGT } \\
\text { level, which was independently associated with total cholesterol both at } \\
\text { baseline and at } 5 \text { years. Liver histology findings in } 6 \text { TS women submitted to } \\
\text { LB included cholangitis }(n=1) \text {, hepatitis C }(n=1) \text {, steatosis }(n=2) \text {, and } \\
\text { normal }(n=2) \text {. Withdrawal of estrogen substitution did not influence serum } \\
\text { liver enzymes }\end{array}$ \\
\hline [98] & $\begin{array}{l}\text { This Mexican cross-sectional study compared } \\
\text { anthropometric, metabolic, hormonal (serum estradiol and } \\
\text { cortisol concentrations), and biochemical variables in } \\
93 \text { women with NAFLD and as many NAFLD-free controls }\end{array}$ & $\begin{array}{l}\text { Ultrasonography and transient } \\
\text { elastography; APRI, NFS }\end{array}$ & $\begin{array}{c}\text { The prevalence of NAFLD in premenopausal, post-menopausal, and PCOS } \\
\text { patients was } 32.2,57.9 \text {, and } 62 \% \text {, respectively. Age, adiposity measures, } \\
\text { fasting glucose, HOMA-IR, and insulin were significantly higher in NAFLD } \\
\text { patients. Compared to NAFLD women, those NAFLD-free women had } \\
\text { significantly higher levels of serum E2 }\end{array}$ \\
\hline [99] & $\begin{array}{l}541 \text { individuals with biopsy-proven NASH were recruited. } \\
\text { LRA was used to determine the association among sex, } \\
\text { menopause, and severity of hepatic fibrosis }\end{array}$ & Liver biopsy & $\begin{array}{l}\text { Compared to pre-menopausal women, men and post-menopausal women } \\
\text { had a higher risk of advanced liver fibrosis suggesting that estrogens may } \\
\text { protect from fibrosis }\end{array}$ \\
\hline [100] & $\begin{array}{l}\text { Survey of questionnaires referring to } 492 \text { patients with TS } \\
\text { (age 17.1-42.5 years) administered by attending physicians } \\
\text { throughout Japan. For comparison purposes, data from the } \\
\text { National Health and Nutrition Survey were used }\end{array}$ & $\begin{array}{l}\text { Liver dysfunction was defined as AST } \\
\geq 41 \mathrm{U} / \mathrm{L}, \mathrm{ALT} \geq 36 \mathrm{U} / \mathrm{L} \text {, or GGT } \geq 60 \mathrm{U} / \mathrm{L}\end{array}$ & $\begin{array}{l}\text { Women with TS tend to become obese from young ages (15-39 years). } \\
\text { Compared to the Japanese general female population, women with TS had } \\
\text { higher prevalence rates of diabetes, hypertension, dyslipidemia, and liver } \\
\text { dysfunction which were associated with increasing BMI rather } \\
\text { than karyotypes }\end{array}$ \\
\hline [101] & $\begin{array}{l}\text { Retrospective analysis of incident fatty liver and/or RLE } \\
\text { during SERM treatment in } 1061 \text { women who were treated } \\
\text { for breast cancer }\end{array}$ & Imaging and/or ALT & $\begin{array}{l}\text { SERM treatment was independently associated with an increased the risk of } \\
\text { incident raised serum ALT levels and/or fatty liver. Consistently, SERM } \\
\text { discontinuation was associated with normalization of raised ALT levels in } \\
\text { virtually all cases. No cases of liver-related death/ progression to cirrhosis } \\
\text { were registered }\end{array}$ \\
\hline [102] & $\begin{array}{l}\text { Analysis of data from } 488 \text { post-menopausal women with } \\
\text { histologically proven NAFLD and self-reported } \\
\text { information on age at menopause }\end{array}$ & Liver histology & $\begin{array}{l}\text { In post-menopausal women with NAFLD, the duration of estrogen } \\
\text { deficiency affected risk of liver fibrosis. }\end{array}$ \\
\hline
\end{tabular}


With regard to men, patients with NAFLD exhibit reduced serum testosterone levels in cross-sectional studies [89,91], and the lower the testosteronemia, the higher the risk of NAFLD [91]. Moreover, hormone replacement therapy improves NAFLD and features of the metabolic syndrome in hypogonadic men [92]. Finally, preliminary evidence also suggests that men rendered hypogonadal by androgen deprivation therapy for prostate cancer have a higher risk of progressive NAFLD [92].

With regard to women, the prototypic state of female hypogonadism, i.e., the Turner syndrome, is associated with an increased prevalence of raised serum liver enzymes, surrogate indices of NAFLD [93-100]. Moreover, it is known that conditions of estrogen deficiency, which may occur either physiologically in post-menopausal women or in hypogonadism-related diseases, are associated with a higher prevalence of NAFLD and advanced liver fibrosis [101,102]. The risk of advanced hepatic fibrosis is associated with longer duration of estrogen deficiency [102].

Post-menopausal status is deemed to be a risk factor for the development and progression of NAFLD in humans [103]. This statement is based on a consistent line of evidence. For example, a case-control study comparing 712 women submitted to oophorectomy to 163 control women found that oophorectomy was an independent predictor of NAFLD [104]. Another large study conducted in 9360 women not only found that the prevalence of NAFLD increased in parallel with increasing age, but also that the prevalence rates of NASH (assessed with a BMI/age/alanine aminotransferase (ALT)/triglyceride (BAAT) index $\geq 3$ ) were $13.2 \%$ vs. $14.9 \%$ in women $>55$ years and obese women with NAFLD, respectively, thus suggesting that post-menopausal age and obesity exert almost the same adverse impact on the risk of developing NASH [105]. At variance with the above studies, in which NAFLD and NASH were diagnosed on a non-invasive basis $[106,107]$, Yang et al., by evaluating data of 541 adults with biopsy-proven NASH, found that men had a higher risk of having more severe liver fibrosis than pre-menopausal women [99]. However, this advantage was lost by women in post-menopausal age whose severity of liver fibrosis was similar to men, suggesting that estrogen protects from hepatic fibrosis. Direct evidence for a beneficial effect of estrogen on the liver was provided by Kamada et al. [107]. These authors reported that ovariectomized mice fed a high-fat and high-cholesterol diet had more severe hepatic histological injury owing to increased intrahepatic infiltration of macrophages, enhanced expression of monocyte chemoattractant protein-1, and increased expression of hepatic inflammatory genes compared to sham-operated controls fed the same diet [107]. Treatment with estrogen was able to improve all the above changes [107].

It is known that treatment with the anti-estrogen tamoxifen may increase the risk of NAFLD and NASH in hysterectomized women [94], and that hormonal replacement therapy is associated with a significant improvement in serum liver enzymes in post-menopausal women with type 2 diabetes [95]. Collectively, these findings suggest that estrogens may protect from the development and progression of NAFLD $[103,108]$.

\subsection{Pathophysiological Mechanisms Linking Hypogonadism with NAFLD}

In health states, gonadal hormones play a key role in regulating total body fat and its regional distribution, as well as insulin sensitivity and glucose homeostasis. Conversely, the deficiency of such hormones, such as seen in hypogonadal states, is typically associated with either the full-blown metabolic syndrome or its individual features, notably including the molecular effectors of hepatic steatogenesis, both in experimental disease and in human NAFLD [109].

The biological mechanisms accounting for the association between hypogonadism and NAFLD are very complex and likely to be variable according to the individual categories of hypogonadism. However, some common pathogenic mechanisms may be identified, which closely mirror the biological end-result of the defective hormones (Table 4) [108]. Given that total and regional adiposity (i.e., subcutaneous versus visceral adipose tissue) may critically depend on sex hormones [103], it is clear that hypogonadism will exhibit those features of either overall or visceral obesity, which are known to increase the risk of development and progression of NAFLD via impaired glucose tolerance, hypertension, and atherogenic dyslipidemia [17]. 
Table 4. Metabolic effects of sex hormones (modified from Shen et al. [108]).

\begin{tabular}{ccccc}
\hline & \multicolumn{2}{c}{ Glucose Metabolism } & \multicolumn{2}{c}{ Lipid Metabolism } \\
\hline Estrogen & $\uparrow$ Insulin clearance & $\uparrow$ Glycogen storage & $\uparrow$ Lipolysis & $\begin{array}{c}\uparrow \text { Cholesterol } \\
\text { removal }\end{array}$ \\
\hline & $\downarrow$ Gluconeogenesis & & $\begin{array}{c}\downarrow \text { Lipogenesis } \\
\downarrow \text { Lipid uptake }\end{array}$ & $\begin{array}{c}\downarrow \text { Cholesterol } \\
\text { synthesis }\end{array}$ \\
\hline Androgen & $\uparrow$ Insulin receptor & $\begin{array}{c}\uparrow \text { Glycogen } \\
\text { synthesis }\end{array}$ & $\begin{array}{c}\uparrow \text { Cholesterol } \\
\text { uptake }\end{array}$ & $\begin{array}{c}\uparrow \text { Cholesterol } \\
\text { synthesis }\end{array}$ \\
\hline & $\downarrow$ Glucose uptake & $\downarrow$ Lipogenesis & $\begin{array}{c}\downarrow \text { Cholesterol } \\
\text { removal }\end{array}$ & \\
\hline
\end{tabular}

In addition to these common pathophysiological features, some specific mechanisms may also be active in either sex. For example, estrogen deficiency in men results in the development of NAFLD associated with typical features of the metabolic syndrome $[110,111]$. Moreover, compared to men, women are physiologically more protected from liver injury associated with oxidative stress thanks to the antioxidant properties of estrogen [112]. This accounts for the increased risk of NAFLD and hepatic fibrosis in post-menopausal women. In rat models, the synthesis of fibroblast growth factor (FGF)-21 declines after ovariectomy, thus contributing to the development of NAFLD [113].

Altered gut microbiota may be another potential factor linking acquired hypogonadism with the development of NAFLD in animal models. Harada et al. reported that, in castrated male mice, androgen deprivation was associated with both increased Firmicutes/Bacteroidetes ratio and number of Lactobacillus species [114]. Intestinal dysbiosis also exacerbated the cardio-metabolic risk in a sex-dependent manner only in male mice fed a high-fat diet, suggesting that dietary stimuli may amplify cardio-metabolic risk factors via altered gut microbiota [113].

Dehydroepiandrosterone (DHEA), the most abundant steroid hormone, affects insulin resistance, oxidative stress, metabolic homeostasis, and fibrogenesis [115]. Based on this biological background, associated with the observation that NASH follows a rapidly progressive course toward cirrhosis in patients with DHEA deficiency owing to panhypopituitarism, Charlton et al. were first in evaluating serum levels of this hormone in fibrosing NASH [115]. Since this pioneering study, others tried to either confirm or dispute this theory and, of the various studies which, over time, addressed this research question (summarized in Table 5 [90,115-119]), all invariably found that biopsy-proven NASH with fibrosis is associated with reduced serum sulfated DHEA (DHEA-S) levels [105]. 
Table 5. Evidence for an association of low serum levels of sulfated dehydroepiandrosterone (DHEA-S) with histologically proven fibrosing NASH.

\begin{tabular}{|c|c|c|c|}
\hline Ref. & Method & Findings & Comment \\
\hline [115] & $\begin{array}{l}\text { Overall, } 439 \text { patients with biopsy-proven mild/advanced NAFLD were } \\
\text { enrolled in the USA } \\
\begin{array}{l}\text { Simple steatosis and NASH with initial fibrosis (i.e., stages 0-2) were } \\
\text { categorized together as "mild NAFLD" }\end{array} \\
\text { NASH with fibrosis stage 3-4 was defined as "advanced NAFLD" } \\
\text { DHEA-S was measured with ELISA. }\end{array}$ & $\begin{array}{l}\text { Compared to patients with mild disease, individuals with advanced NAFLD } \\
\text { exhibited lower serum concentrations of DHEA-S } \\
\text { Decreasing DHEA-S paralleled increasing stages of fibrosis } \\
\text { All patients who had advanced NAFLD exhibited as low DHEA-S levels which } \\
\text { were compatible with adrenal insufficiency in the majority of cases }\end{array}$ & $\begin{array}{l}\text { NASH with advanced stages of } \\
\text { fibrosis is strongly associated with } \\
\text { low serum concentrations of DHEA-S }\end{array}$ \\
\hline [116] & $\begin{array}{c}\text { Data from } 133 \text { Japanese patients with biopsy-proven NAFLD ( } 90 \text { with } \\
\text { NASH: } 73 \text { patients had fibrosis stage 0-2, and } 17 \text { had advanced disease } \\
\text { as defined by fibrosis stage } 3 \text { or } 4 \text { ) were compared to } 399 \text { sex- and } \\
\text { age-matched healthy controls } \\
\text { DHEA-S was measured by CEI }\end{array}$ & $\begin{array}{l}\text { DHEA-S serum concentrations were not statistically different from those found in } \\
\text { the controls } \\
\text { Lower DHEA-S paralleled with increasing stages of fibrosis and this association } \\
\text { remained after adjustment for confounding factors (age, sex, and IR) }\end{array}$ & $\begin{array}{l}\text { Low circulating DHEA-S could have } \\
\text { a causal role in the progression of } \\
\text { NAFLD to fibrosing NASH }\end{array}$ \\
\hline [117] & $\begin{array}{l}\text { 69 Japanese men who had NAFLD diagnosed with ultrasonography } \\
\text { were extracted from a larger sample of } 158 \text { Japanese men who had } \\
\text { neither viral liver diseases nor an alcoholic intake }>20 \mathrm{~g} / \text { day } \\
\text { DHEA-S was measured by RIA }\end{array}$ & $\begin{array}{l}\text { At multivariate regression analysis, serum ALT was positively correlated with } \\
\text { serum DHEA-S, serum triglyceride, and BMI }\end{array}$ & $\begin{array}{l}\text { DHEAS levels are increased in } \\
\text { patients with NAFLD with elevated } \\
\text { ALT levels }\end{array}$ \\
\hline [118] & $\begin{array}{c}160 \text { individuals with morbid obesity were submitted to liver biopsy } \\
\text { which showed SS in } 72 \text {, NASH with fibrosis stage } 0-1 \text { in } 60 \text {, and NASH } \\
\text { with fibrosis stage } \geq 2 \text { in } 12 \text { patients. } 16 \text { had normal liver histology } \\
\text { DHEA-S was measured by ELISA }\end{array}$ & $\begin{array}{l}\text { With one exception, all patients with NASH and fibrosis stage 2-3 had low serum } \\
\text { DHEA concentrations, i.e., }<123 \mu \mathrm{g} / \mathrm{dL} \text {. }\end{array}$ & $\begin{array}{l}\text { Low serum levels of DHEA are very } \\
\text { common among morbidly obese } \\
\text { individuals with NASH and } \\
\text { advanced fibrosis }\end{array}$ \\
\hline [119] & $\begin{array}{l}\text { This study enrolled (a) a training cohort of } 44 \text { patients with biopsy } \\
\text { proven NAFLD and (b) a validation cohort comprising } 105 \text { patients with } \\
\text { biopsy-proven NAFLD and } 26 \text { with biopsy-proven PBC patients. } \\
\text { Moreover, } 48 \text { age-matched healthy controls who had normal liver tests } \\
\text { and no infection with hepatitis viruses were evaluated } \\
\text { Metabolites with LMW were identified with capillary electrophoresis } \\
\text { and liquid chromatography with mass spectrometry }\end{array}$ & $\begin{array}{l}\text { In the training cohort, increasing severity of hepatic fibrosis was associated with a } \\
\text { decrease of DHEA-S and etiocholanolone-S and an increase of 16-OH-DHEA-S. } \\
\text { In the validation cohort, the 16-OH-DHEA-S/DHEA-S ratio and } \\
\text { 16-OH-DHEA-S/etiocholanolone-S ratio were also strongly associated with the } \\
\text { stage of fibrosis. Conversely, DHEA-S, etiocholanolone-S, and the two ratios were } \\
\text { not associated with the stage of fibrosis in patients with PBC }\end{array}$ & $\begin{array}{l}\text { Disturbances in the hormonal profile } \\
\text { are a specific feature of NAFLD, } \\
\text { which could be exploited for } \\
\text { therapeutic purposes }\end{array}$ \\
\hline [90] & $\begin{array}{l}\text { Retrospective case-control study enrolling } 75 \text { Chinese men with IHH } \\
\text { and } 135 \text { age- and sex-matched healthy controls. } \\
\text { The diagnosis of presence/absence of NAFLD was based on } \\
\text { ultrasonography to which only } 63 \text { individuals with IHH were submitted } \\
\text { DHEA-S was measured by chemiluminescence }\end{array}$ & $\begin{array}{l}\text { DHEA-S serum concentrations were significantly more elevated among those } \\
22 \text { patients with IHH and NAFLD than among those } 41 \text { with IHH without NAFLD }\end{array}$ & $\begin{array}{l}\text { There is a complex interaction among } \\
\text { the HPA axis, testosterone deficiency, } \\
\text { and perturbed metabolic health } \\
\text { in men with IHH }\end{array}$ \\
\hline
\end{tabular}

Abbreviation: CEI, chemiluminescent enzyme immunoassay; DHEA-S, sulfated dehydroepiandrosterone; ELISA, enzyme-linked immunosorbent assay; Etiocholanolone-S, $5 \alpha$-androstan- $3 \beta$ ol-17-one sulfate; HPA, hypothalamic-pituitary-adrenal; IHH, idiopathic hypogonadotropic hypogonadism; IR, insulin resistance; LMW, low molecular weight; NASH, nonalcoholic steatohepatitis; 16-OH-DHEA-S, hydroxy-dehydroepiandrosterone sulfate; PBC, primary biliary cholangitis; RIA, radioimmunoassay; SS, simple steatosis. 


\subsection{Principles of Diagnosis and Management}

\subsubsection{Diagnosis}

The diagnosis of hypogonadism-induced NAFLD requires a high index of suspicion in the individual case. Although this topic is not specifically regulated by current guidelines, the exclusion of other competing causes of (steatogenic) liver disease is a part of the general diagnostic philosophy of NAFLD [38,120-122]. On the other side, it seems logical to propose that, in patients with hypogonadism, a first-line non-invasive assessment of the liver should routinely be performed by the endocrinologist in charge of the patient. This may be accomplished by using the same diagnostic approach suggested under Section 2.4 and after exclusion of competing causes of liver disease before referring the patient to the hepatologist whenever fibrosing liver disease is suspected.

\subsubsection{Management}

The general principles of treatment include lifestyle changes, namely dietary restrictions coupled with physical exercise, as well as other interventions chiefly aimed at treating comorbid conditions [123].

The specific principles of treatment are usually differentiated on a sexual basis.

The treatment of choice in male hypogonadism is the administration of testosterone rather than aromatase inhibitors, which raise plasma testosterone levels while reducing E2 [123]. Indeed, in men, circulating levels of E2 exceed those of post-menopausal women; estrogen receptors are expressed in many target tissues, and E2 plays a key role in regulating endocrine axes, such as hypothalamic-pituitary-testicular, as well as growth hormone insulin-like growth factor-1, in preserving the reproductive function, bone health, body composition, carbohydrate homeostasis, and vasomotor stability [124]. Since 2015, testosterone products have to be labeled with a warning on potential cardiovascular risk associated with this hormone, despite the fact that this therapy may actually improve such cardiovascular outcomes [125].

Hypogonadism in women is treated with estrogen replacement through a variety of strategies spanning from treatment with low-dose transdermal E2, oral micronized E2, or per the intramuscular route; after progestin is added, a pill containing both an estrogen and a progestin may be preferable owing to the ease of its use [126].

In conclusion, we strongly suggest that patients with hypogonadism-induced NAFLD should be managed jointly by the endocrinologist and the hepatologist with the specific aim of preventing the progression of both liver-related complications and extra-hepatic manifestations of NAFLD [2,127]. The use of sex hormone replacement therapy in selected cases of primary NAFLD is an interesting topic of research which requires specific experimental studies and clinical trials, and cannot be recommended at present.

\section{GH Deficiency}

\subsection{Epidemiology of GH Deficiency}

GH and its chief mediator, insulin-like growth factor-1 (IGF-1), are mainly under control of the hypothalamic-pituitary somatotropic axis, even if other elements are involved in their homeostasis and secretion. GH and IGF-1, by regulating glucose and lipid metabolism, body composition, and growth, exert a key metabolic role on the liver, adipose tissue, and skeletal muscle both in children and adults [128,129]. Therefore, GH exerts many effects in different tissues, mediated by complex mechanisms, either directly via interaction with GH receptor or indirectly via its mediator IGF-1 [13]. Specifically, in adult healthy subjects, GH promotes the release of free fatty acids (FFA), via lipolysis in the visceral adipose tissue; moreover; GH also stimulates protein synthesis and exerts anabolic effects on muscle and bone tissue, contributing to an increase in lean body mass, muscle strength, and bone mineral density [130]. The effect of GH and its deficiency on glucose metabolism is quite intricate. It is known that GH stimulates gluconeogenesis and glycogenolysis in the liver and inhibits glucose uptake 
in adipose tissue, contrasting insulin signaling. Unexpectedly, GHD determines insulin resistance probably due to the increased FFA flux and glycogen synthesis inhibition, but the exact mechanisms remain to be elucidated $[129,130]$.

The actions of the GH-IGF-1 axis are regulated by a complex intracellular signaling pathway, involving Janus kinase 2 (JAK-2) and signal transducer and the activation of activator of transcription 5 (STAT-5), with regulation of target genes leading to an improvement of systemic insulin resistance and lipolysis in visceral adipose tissue [130]. As known, liver is the main tissue involved in IGF-1 production after GH secretion. IGF-1, after binding IGF-binding proteins and its specific receptors (ubiquitously expressed), contributes to systemic metabolic effects, increasing GH action. However, many other extra-hepatic tissues and the liver itself can produce IGF-1, where it exerts autocrine and paracrine effects in a GH-independent manner [131]. Different elements, such as nutritional status, protein and glucose intake, and inflammatory state, are involved in regulating the peripheral and GH-independent production of IGF-1 [132].

GHD in adults (AGHD), in most cases due to either hypothalamic and pituitary lesions or their treatment, leads to detrimental metabolic consequences typically involved in NAFLD pathogenesis, such as visceral obesity, dyslipidemia, and insulin resistance, carrying an inherently increased prevalence of metabolic syndrome [130], an increased risk of premature atherosclerosis, cardiovascular morbidity/mortality, and poor quality of life $[128,133]$. Based on the finding that untreated AGHD patients exhibit a metabolic syndrome-like phenotype, which is strongly and bi-directionally associated with NAFLD, a potential association between GHD and NAFLD was suggested [134].

Confirming this suggestion, both NAFLD and metabolic syndrome are associated with lower serum GH levels and lower GH and IGF-1 levels were consistently reported in NAFLD patients compared to NAFLD-free controls [135-139]. Moreover, lower GH and IGF-1 levels are also associated with the histological severity of NAFLD [139-141]. Consistently, in a cohort of patients with biopsy-proven NAFLD, hepatic IGF-1 messenger RNA (mRNA) levels were significantly decreased in patients with NASH compared to those with simple steatosis, and inversely associated with the degrees of hepatic steatosis and inflammation [142].

Seen from another perspective, hypothalamic and pituitary disorders, including GHD, are also an increasingly recognized risk factor for the development and progression of secondary forms of NAFLD, which are not reversible following lifestyle changes [143-149]. Indeed, in the last decades, NAFLD was increasingly diagnosed as a hepatic complication of GHD, carrying a high risk of progressing to more severe forms of NAFLD and requiring liver transplantation (Table 6 [143-148]). In a retrospective study, Adams et al. found a prevalence of NAFLD of approximately $2 \%$ in patients with hypothalamic or pituitary disorders. Of concern, these patients developed progressive NAFLD, i.e., with histological evidence of either fibrosis or cirrhosis, only a few years after the diagnosis [143]. Specifically, patients with GHD had a 6.4-fold increased prevalence of NAFLD compared to age-, sex-, and BMI-matched controls; in addition, almost all of a selected subgroup of GHD patients had histological evidence of NASH [144]. In agreement, Ichikawa et al. found that, compared to patients with pituitary dysfunction without GHD, those with GHD had a significantly increased risk of NAFLD [145]. In their case-control study, Hong et al. found that the prevalence of NAFLD was significantly higher in men with hypopituitarism than in healthy controls and that, in NAFLD patients, serum GH levels were lower and inversely correlated with the severity of hepatic steatosis [146]. Conflicting with the findings reported above, however, some studies found a similar prevalence of both NAFLD and MRI-assessed hepatic fat content when comparing cohorts of patients with GHD to GHD-free control subjects [149]. Differences in demographic and anthropometric features among the various cohorts might potentially account for these conflicting results $[147,148]$. The finding that GH replacement therapy induced a small reduction of hepatic fat content in NAFLD patients with GHD [147] offers the reasonable hope to resolve this ongoing scientific controversy by addressing this topic from a therapeutic perspective thanks to adequately sized future large therapeutic trials. 
Table 6. Principal published studies evaluating the association of growth hormone deficiency (GHD) with NAFLD.

\begin{tabular}{|c|c|c|}
\hline Author, Ref. & Method, Cohort, and Diagnostic Criteria & Findings \\
\hline [143] & $\begin{array}{l}\text { Longitudinal cohort study. } \\
879 \text { patients with hypothalamic or pituitary dysfunction. } \\
\text { NAFLD diagnosis based on with imaging and liver enzyme } \\
\text { alteration. Liver biopsy was performed in a subgroup of } 10 \\
\text { NAFLD patients }\end{array}$ & $\begin{array}{c}\text { NAFLD was found in } 21 \text { patients with metabolic } \\
\text { syndrome-like phenotype (prevalence of } 2.3 \% \text { ). } \\
\text { The majority of biopsy-proven NAFLD patients } \\
\text { exhibited advanced forms, i.e., cirrhosis and NASH } \\
\text { with fibrosis }\end{array}$ \\
\hline [144] & $\begin{array}{l}\text { Cross-sectional retrospective study. } \\
66 \text { adults with hypopituitarism and GHD compared to } 83 \\
\text { age-, gender-, and BMI-matched healthy controls. } \\
19 \text { patients received GH replacement therapy according to } \\
\text { clinical recommendations. } \\
\text { GHD diagnosis based on insulin tolerance test or GH } \\
\text { releasing peptide-2 test. } \\
\text { NAFLD diagnosis based on ultrasound. Liver biopsy was } \\
\text { performed in } 16 \text { patients }\end{array}$ & $\begin{array}{l}\text { NAFLD prevalence was significantly higher of } 6.4 \text {-fold } \\
\text { in GHD group compared to healthy controls, } \\
\text { independently of obesity. Overweight and insulin } \\
\text { resistance were more prevalent in GHD group with } \\
\text { NAFLD. Histological NASH was found in } 14 \text { out of } 16 . \\
\text { GHRT was associated with reduction of liver enzyme } \\
\text { and improvement of steatosis and fibrosis }\end{array}$ \\
\hline [146] & $\begin{array}{l}\text { Cross-sectional observational study. } \\
34 \text { Korean patients with hypopituitarism and } 40 \text { age- and } \\
\text { sex-matched lean healthy controls. } \\
\text { GHD defined as peak GH level of }<3 \mathrm{ng} / \mathrm{mL} \text {. } \\
\text { NAFLD diagnosis based on ultrasound }\end{array}$ & $\begin{array}{l}\text { Prevalence of fatty liver was significantly higher in men } \\
\text { with hypopituitarism than controls. Among NAFLD } \\
\text { patients with hypopituitarism, GH levels were lower } \\
\text { and negatively correlated with degree of steatosis }\end{array}$ \\
\hline [147] & $\begin{array}{l}\text { Cross-sectional study. } \\
28 \text { patients with GHD and } 24 \text { age- and BMI-matched controls. } \\
12 \text { GHD patients evaluated longitudinally before and } \\
6 \text { months after start of GHRT. } \\
\text { GHD diagnosis based on GH response }<3 \mathrm{mg} / \mathrm{L} \text { after } \\
\text { glucagon stimulation. } \\
\text { NAFLD defined as MRI-assessed intrahepatic lipid content } \\
\text { (IHLC) }>5.6 \%\end{array}$ & $\begin{array}{l}\text { Although GHD patients exhibited higher visceral fat, } \\
\text { the } 2 \text { groups presented similar liver enzyme levels and } \\
\text { IHLC. GHRT was associated with reduction of } \\
\text { subcutaneous and visceral adipose tissue and, in those } \\
\text { with baseline high liver fat, with a positive trend in } \\
\text { reduction of IHLC }\end{array}$ \\
\hline
\end{tabular}

Abbreviations: NAFLD, nonalcoholic fatty liver disease; NASH, nonalcoholic steatohepatitis; $\mathrm{GH}$, growth hormone; GHD, growth hormone deficiency; BMI, body mass index; GHRT, growth hormone replacement therapy; IHCL, intrahepatic lipid content.

\subsection{Pathophysiological Mechanisms Linking GHD with NAFLD}

Based on the metabolic effects of the GH-IGF-1 axis on the adipose tissue and the liver, different pathogenic mechanisms were suggested as a possible link between GHD and NAFLD [150,151], notably including insulin resistance, which is a shared common denominator of both diseases. It was repeatedly observed that mouse models with liver-specific deletion of GH receptor (GHRLD) develop insulin resistance, hepatic steatosis, dyslipidemia, and increased de novo lipogenesis [152,153]. In a cell culture model, Rufinatscha et al. demonstrated a decreased hepatic insulin sensitivity in GHR knockdown hepatocytes, which was not completely reversed by IGF-1 administration, suggesting an important role of GH on hepatic glucose metabolism [142]. The development of NAFLD in liver-specific JAK2-deficient (JAK2L) [154] and liver-specific STAT5-deficient mice [155] highlights the importance of the GH signaling pathway.

Furthermore, GHRLD mice also exhibit alterations in mitochondrial structure and function and increased oxidative stress with enhanced production of ROS, which in turn further impairs mitochondrial function. Interestingly, these hepatic modifications improve following the administration of either GH or IGF-1, suggesting a GH-independent effect of IGF-1 on the liver [156,157]. In this context, emerging data also suggest that melatonin (a pleiotropic hormone primarily known for its 
regulatory role in circadian rhythms, sleep, retinal functions, and the immune system) may have a relevant role as a scavenger of ROS with antioxidant properties in individuals with features of the metabolic syndrome [158]. Interestingly, new experimental studies also indicate that, in mouse liver, melatonin is also needed for insulin-stimulated phosphatidylinositol 3-kinase (PI3K)-protein kinase B activity. In rats, it seems to suppress the hepatic glucose production, and, in the human hepatocyte cell line HepG2, it activates glycogen synthesis via a protein kinase C (PKC) $\zeta-A K T$-glycogen synthase kinase-3 $\beta$ (GSK3 $\beta$ ) pathway [158]. Moreover, in animal models with high-fat diet (HFD)-induced NAFLD, melatonin seems to be involved in reducing liver and mitochondrial alterations due to oxidative stress and in improving steatosis and histological features [159].

Additionally, a systemic low-grade inflammatory state characterized by increased levels of pro-inflammatory cytokines may also promote the development and progression of NAFLD in GHD patients. In GHRLD mice, Fan et al. showed an increased hepatic expression of fibrogenic and inflammatory genes, such as tumor necrosis- $\alpha$ (TNF- $\alpha$ ) and C-C motif chemokine ligand 3 (CCL3) [152]. In humans, Takahashi et al. found a reduction in TNF- $\alpha$ and C-reactive protein after GH replacement therapy [160]. Another biological activity of GH pertains to its control of hepatocyte proliferation, as demonstrated by GHRLD mice exhibiting impaired hepatocyte regeneration. Instead, IGF-1 seems to affect the biology of hepatic stellate cells by inducing their senescence and inactivation, thereby limiting hepatic fibrogenesis [161].

\subsection{Principles of Diagnosis and Management}

Provocative tests of GH secretion are used to identify GHD, considering the pulsatile GH secretion. The insulin tolerance test, deemed to be the standard test, and the GH-releasing hormone (GHRH)-arginine test, well tolerated, are both used in clinical practice for the diagnosis of GHD. The identification of GH cut-off values for a definite diagnosis of GHD is difficult owing to the lack of normal ranges standardized according to demographic and anthropometric variables. However, a cut-off of $4.1 \mathrm{~g} / \mathrm{L}$ for the GHRH-arginine test and $<5.1 \mathrm{~g} / \mathrm{L}$ for the insulin tolerance test are considered suggestive for GHD [162,163].

In contrast to pediatric populations, GH replacement therapy should be administrated only in severe and symptomatic forms of AGHD, aiming at reducing visceral fat mass, improving lipid profile, and decreasing cardiovascular morbidity [161]. Despite exerting many positive metabolic effects, GH replacement therapy, however, is not indicated as a possible treatment for NAFLD in AGHD patients [163]. About two decades ago, Takano et al. reported one of the first cases of fatty liver significantly improving after GH replacement therapy in a young patient with pan-hypopituitarism [164]. Subsequently, the role of GH replacement therapy in improving NAFLD in AGHD patients was confirmed [164]. Indeed, GH replacement therapy reduces liver enzymes, and improves hepatic steatosis and biomarkers of inflammation and fibrosis $[164,165]$. Furthermore, the interruption of GH replacement therapy in adults with childhood onset GHD may increase the risk of developing metabolic complications, including dyslipidemia and NAFLD, indirectly suggesting that long-term GH replacement therapy plays a role in preventing cardio-metabolic risk $[166,167]$.

However, considering the negative impact of weight gain on the efficacy of GH replacement therapy [164], it can be hypothesized that other factors may potentially contribute to the progression of NAFLD. Therefore, in GHD adult and pediatric subjects, GH replacement therapy covers a major role in determining an improvement on clinical and histological features of NAFLD, confirming a predominant role of GHD on the development of NAFLD [144,165]. Instead, lifestyle changes merely contribute an additional effect to specific therapy, but they are unable to prevent the progression of liver disease in this type of secondary NAFLD [144,149]. Moreover, patients with GHD often have concomitant derangements of other endocrine pathways, such as thyroid, gonadal, and glucocorticoid hormones, which may all play a major role in the development of secondary NAFLD and NASH via obesity and insulin resistance [132]. 
In conclusion, based on the evidence reported above, screening for NAFLD seems justified in all patients with GHD. Although data are still controversial, considering its beneficial effects on insulin resistance, inflammation, oxidative stress, and fibrosis, the administration of exogenous GH and especially IGF-1 has a strong rationale and potential clinical applications in the treatment of NAFLD secondary to hypothalamic-pituitary dysfunction(s). Conversely, whether and in which subset of individuals with primary NAFLD hormone replacement therapy with GH/IGF-1 should be tested remains the object of experimental and clinical research.

\section{Conclusions}

NAFLD designates the complex array of metabolic, histological, and extra-hepatic consequences, which result from the intra-hepatic deposition of ectopic fat. As a reflection of our incomplete understanding of its pathogenesis, our capacity to treat NAFLD lags far behind our ever-increasing understanding of the global epidemiological, clinical, and economic burden of disease.

Given that they are well-characterized forms of secondary NAFLD, PCOS, hypothyroidism, hypogonadism, and GHD were extensively discussed here with specific reference to their epidemiological hallmarks, pathophysiological features, and principles of diagnosis and management.

The findings that both androgen excess (such as observed in certain phenotypes of PCOS) and androgen deficiency (such as seen in male hypogonadism) are associated with an increased risk of NAFLD strongly suggest that the contribution of sex hormones to the development and progression of NAFLD is far from simple. It was logically postulated that metabolic health is associated with a specific androgen/estrogen/androgen ratio in either sex, and changes of this ratio will induce metabolic derangements and NAFLD [168]. In male rodents, androgens, by regulating genes involved in hepatic lipogenesis and glucose metabolism, protect from NAFLD and insulin resistance through a dual mechanism: via androgen receptor signaling and via estrogen receptor signaling (following aromatization of testosterone to estradiol) [169]. In contrast, in female rodents, it is estradiol which protects from NAFLD, whereas androgens promote both NAFLD and dysglycemia [169]. These notions receive credibility by the acknowledged activity of sex hormones and their receptors in regulating liver energy homeostasis and body fat distribution [110]. Stated otherwise, androgen excess in women and androgen deficiency in men both manifest with a shared dysmetabolic phenotype, featuring abdominal obesity, type 2 diabetes, insulin resistance, NAFLD, and excess cardiovascular risk (Table 3).

We are not aware of any comparative studies specifically addressing similarities and differences between the natural course of NAFLD secondary to endocrine disorders as opposed to the course of primary NAFLD. That said, we point out that the development of hepatocellular carcinoma in individuals with hypothyroidism was reported (reviewed in Reference [19]). This implies that this specific form of NAFLD has the potential to run the complete course of NAFLD from uncomplicated simple steatosis to end-stage liver disease. In contrast, while the presence of advanced fibrosis was consistently reported in patients with PCOS [28], to our knowledge, there are currently no published reports of well-documented cases of hepatocellular carcinoma occurring in patients with PCOS. As far as hypogonadism is concerned, Klinefelter's syndrome is exceptionally associated with primary biliary cholangitis rather than with NASH-cirrhosis [170,171]. Turner syndrome is rarely associated with NASH-cirrhosis [172]. However, we are not aware of any cases of NAFLD-related hepatocellular carcinoma occurring in hypogonadic patients.

Collectively, the above-discussed forms of NAFLD secondary to some common endocrine derangements represent a naturally occurring disease model of NAFLD in humans. Therefore, a better understanding of their features promises to disclose novel clinical associations and innovative therapeutic approaches, which may potentially be exploited for use also in selected cases of primary NAFLD. However, further basic and clinical research is certainly needed to achieve this ambitious aim.

Funding: This research received no external funding. 
Conflicts of Interest: The authors declare no conflict of interest.

\section{Abbreviations}

$\mathrm{ACTH}$

AGHD

AMPK

apo

BAAT index

BMI

CCL3

CI

ERK

FT4

$\mathrm{GH}$

GHD

GHRH

GHRLD

HDL

hypertension

IGF-1

JAK-2

JAK2L

JNK

LDL

LH

MAPK

MKK3

MKK-4

MRI

MRS

NAFLD

NASH

OR

PCOS

PI3K

PKC

$\operatorname{PPAR} \alpha$

ROS

SREBP-1C

STAT-5

TNF- $\alpha$

TSH

VLDL adrenocorticotropic hormone

adult growth hormone deficiency

AMP-activated protein kinase

apolipoprotein

body mass index, age, ALT, and triglyceride

body mass index

C-C motif chemokine ligand 3

confidence interval

extracellular signal-regulated kinase

free thyroxine

growth hormone

growth hormone deficiency

GH-releasing hormone

liver-specific deletion of GH receptor

high-density lipoprotein

arterial hypertension

insulin-like growth factor-1

Janus kinase 2

liver-specific JAK2-deficient

c-Jun N-terminal kinase

low-density lipoprotein

luteinizing hormone

mitogen-activated protein kinase

MAP kinase-activated protein kinase-3

MAP kinase-activated protein kinase- 4

magnetic resonance imaging

magnetic resonance spectroscopy

nonalcoholic fatty liver disease

nonalcoholic steatohepatitis

odds ratio

polycystic ovary syndrome

phosphoinositide 3-kinase

protein kinase $\mathrm{C}$

peroxisome proliferator-activated receptor- $\alpha$

reactive oxygen species

sterol regulatory element-binding

signal transducer and activator of transcription 5

tumor necrosis factor- $\alpha$

thyroid-stimulating hormone

very low-density lipoprotein

\section{References}

1. Petäjä, E.M.; Yki-Järvinen, H. Definitions of Normal Liver Fat and the Association of Insulin Sensitivity with Acquired and Genetic NAFLD-A Systematic Review. Int. J. Mol. Sci. 2016, 17, 633.

2. Italian Association for the Study of the Liver (AISF). AISF position paper on nonalcoholic fatty liver disease (NAFLD): Updates and future directions. Dig. Liver Dis. 2017, 49, 471-483. [CrossRef] [PubMed]

3. Younossi, Z.; Tacke, F.; Arrese, M.; Sharma, B.C.; Mostafa, I.; Bugianesi, E.; Wong, V.W.; Yilmaz, Y.; George, J.; Fan, J.; et al. Global Perspectives on Non-alcoholic Fatty Liver Disease and Non-alcoholic Steatohepatitis. Hepatology 2019, 69, 2672-2682. [CrossRef] [PubMed] 
4. Fazel, Y.; Koenig, A.B.; Sayiner, M.; Goodman, Z.D.; Younossi, Z.M. Epidemiology and natural history of non-alcoholic fatty liver disease. Metabolism 2016, 65, 1017-1025. [CrossRef]

5. Vilar-Gomez, E.; Calzadilla-Bertot, L.; Wai-Sun Wong, V.; Castellanos, M.; Aller-de la Fuente, R.; Metwally, M.; Eslam, M.; Gonzalez-Fabian, L.; Alvarez-Quiñones Sanz, M.; Conde-Martin, A.F.; et al. Fibrosis Severity as a Determinant of Cause-Specific Mortality in Patients With Advanced Nonalcoholic Fatty Liver Disease: A Multi-National Cohort Study. Gastroenterology 2018, 155, 443-457. [CrossRef] [PubMed]

6. European Association for the Study of the Liver (EASL); European Association for the Study of Diabetes (EASD); European Association for the Study of Obesity (EASO). EASL-EASD-EASO Clinical Practice Guidelines for the management of non-alcoholic fatty liver disease. J. Hepatol. 2016, 64, 1388-1402. [CrossRef] [PubMed]

7. Chalasani, N.; Younossi, Z.; Lavine, J.E.; Charlton, M.; Cusi, K.; Rinella, M.; Harrison, S.A.; Brunt, E.M.; Sanyal, A.J. The diagnosis and management of nonalcoholic fatty liver disease: Practice guidance from the American Association for the Study of Liver Diseases. Hepatology 2018, 67, 328-357. [CrossRef] [PubMed]

8. Lonardo, A.; Ballestri, S.; Marchesini, G.; Angulo, P.; Loria, P. Nonalcoholic fatty liver disease: a precursor of the metabolic syndrome. Dig. Liver Dis. 2015, 47, 181-190. [CrossRef] [PubMed]

9. Iwen, K.A.; Oelkrug, R.; Kalscheuer, H.; Brabant, G. Metabolic Syndrome in Thyroid Disease. Front. Horm. Res. 2018, 49, 48-66.

10. Rastrelli, G.; Filippi, S.; Sforza, A.; Maggi, M.; Corona, G. Metabolic Syndrome in Male Hypogonadism. Front. Horm. Res. 2018, 49, 131-155.

11. Dwyer, A.A.; Quinton, R. The Metabolic Syndrome in Central Hypogonadotrophic Hypogonadism. Front. Horm. Res. 2018, 49, 156-169. [PubMed]

12. Pasquali, R. Metabolic Syndrome in Polycystic Ovary Syndrome. Front. Horm. Res. 2018, 49, 114-130. [PubMed]

13. Miljić, D.; Popovic, V. Metabolic Syndrome in Hypopituitarism. Front. Horm. Res. 2018, 49, 1-19. [PubMed]

14. Lonardo, A.; Nascimbeni, F.; Mantovani, A.; Targher, G. Hypertension, diabetes, atherosclerosis and NASH: Cause or consequence? J. Hepatol. 2018, 68, 335-352. [CrossRef] [PubMed]

15. Angulo, P. Nonalcoholic fatty liver disease. N. Engl. J. Med. 2002, 346, 1221-1231. [CrossRef] [PubMed]

16. Lonardo, A.; Carani, C.; Carulli, N.; Loria, P. 'Endocrine NAFLD' a hormonocentric perspective of nonalcoholic fatty liver disease pathogenesis. J. Hepatol. 2006, 44, 1196-1207. [CrossRef] [PubMed]

17. Loria, P.; Carulli, L.; Bertolotti, M.; Lonardo, A. Endocrine and liver interaction: the role of endocrine pathways in NASH. Nat. Rev. Gastroenterol. Hepatol. 2009, 6, 236-247. [CrossRef] [PubMed]

18. Manka, P.; Bechmann, L.; Best, J.; Sydor, S.; Claridge, L.C.; Coombes, J.D.; Canbay, A.; Moeller, L.; Gerken, G.; Wedemeyer, H.; et al. Low Free Triiodothyronine Is Associated with Advanced Fibrosis in Patients at High Risk for Nonalcoholic Steatohepatitis. Dig. Dis. Sci. 2019. [CrossRef]

19. Lonardo, A.; Ballestri, S.; Mantovani, A.; Nascimbeni, F.; Lugari, S.; Targher, G. Pathogenesis of hypothyroidism-induced NAFLD: Evidence for a distinct disease entity? Dig. Liver Dis. 2019, 5, 462-470. [CrossRef]

20. McCartney, C.R.; Marshall, J.C. Clinical practice. Polycystic ovary syndrome. N. Engl. J. Med. 2016, 375, 54-64. [CrossRef]

21. Anagnostis, P.; Tarlatzis, B.C.; Kauffman, R.P. Polycystic ovarian syndrome (PCOS): long-term metabolic consequences. Metabolism 2018, 86, 33-43. [CrossRef]

22. Targher, G.; Zoppini, G.; Bonora, E.; Moghetti, P. Hemostatic and fibrinolytic abnormalities in polycystic ovary syndrome. Semin. Thromb. Hemost. 2014, 40, 600-618.

23. Stein, I.F.; Leventhal, M.L. Amenorrhea associated with bilateral polycystic ovaries. Am. J. Obstet. Gynecol. 1935, 29, 181-191. [CrossRef]

24. The Rotterdam ESHRE/ASRM-sponsored PCOS consensus workshop group. Revised 2003 consensus on diagnostic criteria and long-term health risks related to polycystic ovary syndrome (PCOS). Hum. Reprod. 2004, 19, 41-47. [CrossRef]

25. Sirmans, S.M.; Pate, K.A. Epidemiology, diagnosis, and management of polycystic ovary syndrome. Clin. Epidemiol. 2014, 6, 1-13. [CrossRef] [PubMed]

26. Yildiz, B.O.; Bozdag, G.; Yapici, Z.; Esinler, I.; Yarali, H. Prevalence, phenotype and cardiometabolic risk of polycystic ovary syndrome under different diagnostic criteria. Hum. Reprod. 2012, 27, 3067-3073. [CrossRef] [PubMed] 
27. Targher, G.; Rossini, M.; Lonardo, A. Evidence that non-alcoholic fatty liver disease and polycystic ovary syndrome are associated by necessity rather than chance: a novel hepato-ovarian axis? Endocrine 2016, 51, 211-221. [CrossRef] [PubMed]

28. Setji, T.L.; Holland, N.D.; Sanders, L.L.; Pereira, K.C.; Diehl, A.M.; Brown, A.J. Nonalcoholic steatohepatitis and nonalcoholic fatty liver disease in young women with polycystic ovary syndrome. J. Clin. Endocrinol. Metab. 2006, 91, 1741-1747. [CrossRef] [PubMed]

29. Brzozowska, M.M.; Ostapowicz, G.; Weltman, M.D. An association between non-alcoholic fatty liver disease and polycystic ovarian syndrome. J. Gastroenterol. Hepatol. 2009, 24, 243-247. [CrossRef]

30. Hossain, N.; Stepanova, M.; Afendy, A.; Nader, F.; Younossi, Y.; Rafiq, N.; Goodman, Z.; Younossi, Z.M. Non-alcoholic steatohepatitis (NASH) in patients with polycystic ovarian syndrome (PCOS). Scand. J. Gastroenterol. 2011, 46, 479-484. [CrossRef]

31. Wu, J.; Yao, X.Y.; Shi, R.X.; Liu, S.F.; Wang, X.Y. A potential link between polycystic ovary syndrome and non-alcoholic fatty liver disease: an update meta-analysis. Reprod. Health 2018, 15, 77. [CrossRef] [PubMed]

32. Jones, H.; Sprung, V.S.; Pugh, C.J.; Daousi, C.; Irwin, A.; Aziz, N.; Adams, V.L.; Thomas, E.L.; Bell, J.D.; Kemp, G.J.; et al. Polycystic ovary syndrome with hyperandrogenism is characterized by an increased risk of hepatic steatosis compared to non-hyperandrogenic PCOS phenotypes and healthy controls, independent of obesity and insulin resistance. J. Clin. Endocrinol. Metab. 2012, 97, 3709-3716. [CrossRef] [PubMed]

33. Kim, J.J.; Kim, D.; Yim, J.Y.; Kang, J.H.; Han, K.H.; Kim, S.M.; Hwang, K.R.; Ku, S.Y.; Suh, C.S.; Kim, S.H.; et al. Polycystic ovary syndrome with hyperandrogenism as a risk factor for non-obese non-alcoholic fatty liver disease. Aliment Pharmacol. Ther. 2017, 45, 1403-1412. [CrossRef] [PubMed]

34. Kumarendran, B.; O’Reilly, M.W.; Manolopoulos, K.N.; Toulis, K.A.; Gokhale, K.M.; Sitch, A.J.; Wijeyaratne, C.N.; Coomarasamy, A.; Arlt, W.; Nirantharakumar, K. Polycystic ovary syndrome, androgen excess, and the risk of nonalcoholic fatty liver disease in women: a longitudinal study based on a United Kingdom primary care database. PLoS Med. 2018, 15, e1002542. [CrossRef] [PubMed]

35. Vassilatou, E.; Lafoyianni, S.; Vryonidou, A.; Ioannidis, D.; Kosma, L.; Katsoulis, K.; Papavassiliou, E.; Tzavara, I. Increased androgen bioavailability is associated with non-alcoholic fatty liver disease in women with polycystic ovary syndrome. Hum. Reprod. 2010, 25, 212-220. [CrossRef] [PubMed]

36. Cussons, A.J.; Watts, G.F.; Mori, T.A.; Stuckey, B.G. Omega-3 fatty acid supplementation decreases liver fat content in polycystic ovary syndrome: a randomized controlled trial employing proton magnetic resonance spectroscopy. J. Clin. Endocrinol. Metab. 2009, 94, 3842-3848. [CrossRef]

37. Dawson, A.J.; Sathyapalan, T.; Smithson, J.A.; Vince, R.V.; Coady, A.M.; Ajjan, R.; Kilpatrick, E.S.; Atkin, S.L. A comparison of cardiovascular risk indices in patients with polycystic ovary syndrome with and without coexisting nonalcoholic fatty liver disease. Clin. Endocrinol. 2014, 80, 843-849. [CrossRef] [PubMed]

38. Byrne, C.D.; Patel, J.; Scorletti, E.; Targher, G. Tests for diagnosing and monitoring non-alcoholic fatty liver disease in adults. BMJ 2018, 362, k2734. [CrossRef]

39. Baptiste, C.G.; Battista, M.C.; Trottier, A.; Baillargeon, J.P. Insulin and hyperandrogenism in women with polycystic ovary syndrome. J. Steroid Biochem. Mol. Biol. 2010, 122, 42-52. [CrossRef]

40. Munir, I.; Yen, H.W.; Geller, D.H.; Torbati, D.; Bierden, R.M.; Weitsman, S.R.; Agarwal, S.K.; Magoffin, D.A. Insulin augmentation of 17alpha-hydroxylase activity is mediated by phosphatidyl inositol 3- kinase but not extracellular signal-regulated kinase-1/2 in human ovarian theca cells. Endocrinology 2004, 145, 175-183. [CrossRef]

41. Wickenheisser, J.K.; Nelson-DeGrave, V.L.; McAllister, J.M. Human ovarian theca cells in culture. Trends Endocrinol. Metab. 2006, 17, 65-71. [CrossRef] [PubMed]

42. Abbott, D.H.; Dumesic, D.A.; Levine, J.E. Hyperandrogenic origins of polycystic ovary syndrome-Implications for pathophysiology and therapy. Expert Rev. Endocrinol. Metab. 2019, 14, 131-143. [CrossRef] [PubMed]

43. Schiffer, L.; Kempegowda, P.; Arlt, W.; O’Reilly, M.W. MECHANISMS IN ENDOCRINOLOGY: The sexually dimorphic role of androgens in human metabolic disease. Eur. J. Endocrinol. 2017, 177, R125-R143. [CrossRef] [PubMed]

44. Du, Q.; Wang, Y.J.; Yang, S.; Wu, B.; Han, P.; Zhao, Y.Y. A systematic review and meta-analysis of randomized controlled trials comparing pioglitazone versus metformin in the treatment of polycystic ovary syndrome. Curr. Med. Res. Opin. 2012, 28, 723-730. [CrossRef] [PubMed] 
45. Tzotzas, T.; Karras, S.N.; Katsiki, N. Glucagon-like peptide-1 (GLP-1) receptor agonists in the treatment of obese women with polycystic ovary syndrome. Curr. Vasc. Pharmacol. 2017, 15, 218-229. [CrossRef] [PubMed]

46. Frøssing, S.; Nylander, M.; Chabanova, E.; Frystyk, J.; Holst, J.J.; Kistorp, C.; Skouby, S.O.; Faber, J. Effect of liraglutide on ectopic fat in polycystic ovary syndrome: A randomized clinical trial. Diabetes Obes. Metab. 2018, 20, 215-218. [CrossRef] [PubMed]

47. Chaker, L.; Bianco, A.C.; Jonklaas, J.; Peeters, R.P. Hypothyroidism. Lancet 2017, 390, 1550-1562. [CrossRef]

48. Sinha, R.A.; Singh, B.K.; Yen, P.M. Thyroid hormone regulation of hepatic lipid and carbohydrate metabolism. Trends Endocrinol. Metab. 2014, 25, 538-545. [CrossRef] [PubMed]

49. Sinha, R.A.; Singh, B.K.; Yen, P.M. Direct effects of thyroid hormones on hepatic lipid metabolism. Nat. Rev. Endocrinol. 2018, 14, 259-269. [CrossRef]

50. Kar, K.; Sinha, S. Variations of adipokines and insulin resistance in primary hypothyroidism. J. Clin. Diagn Res. 2017, 11, BC07-BC09. [CrossRef] [PubMed]

51. Leonhardt, U.; Ritzel, U.; Schäfer, G.; Becker, W.; Ramadori, G. Serum leptin levels in hypo and hyperthyroidism. J. Endocrinol. 1998, 157, 75-79. [CrossRef]

52. Mantovani, A.; Grani, G. Thyroid Dysfunction and Nonalcoholic Fatty Liver Disease: We Need New Larger and Well-Designed Longitudinal Studies. Dig. Dis. Sci. 2018, 63, 1970-1976. [CrossRef]

53. Liangpunsakul, S.; Chalasani, N. Is hypothyroidism a risk factor for non-alcoholic steatohepatitis? J. Clin. Gastroenterol. 2003, 37, 340-343. [CrossRef] [PubMed]

54. Xu, C.; Xu, L.; Yu, C.; Miao, M.; Li, Y. Association between thyroid function and nonalcoholic fatty liver disease in euthyroid elderly Chinese. Clin. Endocrinol. (Oxf.) 2011, 75, 240-246. [CrossRef] [PubMed]

55. Zhang, J.; Sun, H.; Chen, L.; Zheng, J.; Hu, X.; Wang, S.; Chen, T. Relationship between serum TSH level with obesity and NAFLD in euthyroid subjects. J. Huazhong Univ. Sci. Technol. Med. Sci. 2012, 32, 47-52. [CrossRef] [PubMed]

56. Ittermann, T.; Haring, R.; Wallaschofski, H.; Baumeister, S.E.; Nauck, M.; Dörr, M.; Lerch, M.M.; Meyer zu Schwabedissen, H.E.; Rosskopf, D.; Völzke, H. Inverse association between serum free thyroxine levels and hepatic steatosis: Results from the Study of Health in Pomerania. Thyroid 2012, 22, 568-574. [CrossRef] [PubMed]

57. Pagadala, M.R.; Zein, C.O.; Dasarathy, S.; Yerian, L.M.; Lopez, R.; McCullough, A.J. Prevalence of hypothyroidism in nonalcoholic fatty liver disease. Dig. Dis. Sci. 2012, 57, 528-534. [CrossRef] [PubMed]

58. Chung, G.E.; Kim, D.; Kim, W.; Yim, J.Y.; Park, M.J.; Kim, Y.J.; Yoon, J.H.; Lee, H.S. Non-alcoholic fatty liver disease across the spectrum of hypothyroidism. J. Hepatol. 2012, 57, 150-156. [CrossRef]

59. Xu, L.; Ma, H.; Miao, M.; Li, Y. Impact of subclinical hypothyroidism on the development of non-alcoholic fatty liver disease: A prospective case-control study. J. Hepatol. 2012, 57, 1153-1154. [CrossRef]

60. Carulli, L.; Ballestri, S.; Lonardo, A.; Lami, F.; Violi, E.; Losi, L.; Bonilauri, L.; Verrone, A.M.; Odoardi, M.R.; Scaglioni, F.; et al. Is nonalcoholic steatohepatitis associated with a high-though-normal thyroid stimulating hormone level and lower cholesterol levels? Intern. Emerg. Med. 2013, 8, 297-305. [CrossRef] [PubMed]

61. Eshraghian, A.; Dabbaghmanesh, M.H.; Eshraghian, H.; Fattahi, M.R.; Omrani, G.R. Nonalcoholic fatty liver disease in a cluster of Iranian population: Thyroid status and metabolic risk factors. Arch. Iran. Med. 2013, 16, 584-589. [PubMed]

62. Posadas-Romero, C.; Jorge-Galarza, E.; Posadas-Sánchez, R.; Acuña-Valerio, J.; Juárez-Rojas, J.G.; Kimura-Hayama, E.; Medina-Urrutia, A.; Cardoso-Saldaña, G.C. Fatty liver largely explains associations of subclinical hypothyroidism with insulin resistance, metabolic syndrome, and subclinical coronary atherosclerosis. Eur. J. Endocrinol. 2014, 171, 319-325. [CrossRef]

63. Tao, Y.; Gu, H.; Wu, J.; Sui, J. Thyroid function is associated with non-alcoholic fatty liver disease in euthyroid subjects. Endocr. Res. 2015, 40, 74-78. [CrossRef]

64. Liu, G.; Zheng, X.; Guan, L.; Jiang, Z.; Lin, H.; Jiang, Q.; Zhang, N.; Zhang, Y.; Zhang, X.; Yu, C.; et al. Free triiodothyronine levels are positively associated with non-alcoholic fatty liver disease in euthyroid middle-aged subjects. Endocr. Res. 2015, 40, 188-193. [CrossRef] [PubMed]

65. Ding, W.J.; Wang, M.M.; Wang, G.S.; Shen, F.; Qin, J.J.; Fan, J.G. Thyroid function is associated with non-alcoholic fatty liver disease in chronic hepatitis B-infected subjects. J. Gastroenterol. Hepatol. 2015, 30, 1753-1758. [CrossRef] 
66. Parikh, P.; Phadke, A.; Sawant, P. Prevalence of hypothyroidism in nonalcoholic fatty liver disease in patients attending a tertiary hospital in western India. Indian. J. Gastroenterol. 2015, 34, 169-173.

67. Ludwig, U.; Holzner, D.; Denzer, C.; Greinert, A.; Haenle, M.M.; Oeztuerk, S.; Koenig, W.; Boehm, B.O.; Mason, R.A.; Kratzer, W.; et al. Subclinical and clinical hypothyroidism and non-alcoholic fatty liver disease: A cross-sectional study of a random population sample aged 18 to 65 years. BMC Endocr. Disord. 2015, 15, 41. [CrossRef] [PubMed]

68. Lee, K.W.; Bang, K.B.; Rhee, E.J.; Kwon, H.J.; Lee, M.Y.; Cho, Y.K. Impact of hypothyroidism on the development of non-alcoholic fatty liver disease: A 4-year retrospective cohort study. Clin. Mol. Hepatol. 2015, 21, 372-378. [CrossRef] [PubMed]

69. Bril, F.; Kadiyala, S.; Portillo Sanchez, P.; Sunny, N.E.; Biernacki, D.; Maximos, M.; Kalavalapalli, S.; Lomonaco, R.; Suman, A.; Cusi, K. Plasma thyroid hormone concentration is associated with hepatic triglyceride content in patients with type 2 diabetes. J. Investig. Med. 2016, 64, 63-68. [CrossRef] [PubMed]

70. Bano, A.; Chaker, L.; Plompen, E.P.; Hofman, A.; Dehghan, A.; Franco, O.H.; Janssen, H.L.; Darwish Murad, S.; Peeters, R.P. Thyroid function and the risk of nonalcoholic fatty liver disease: The Rotterdam study. J. Clin. Endocrinol. Metab. 2016, 101, 3204-3211. [CrossRef] [PubMed]

71. Gökmen, F.Y.; Ahbab, S.; Ataoğlu, H.E.; Türker, B.Ç.; Çetin, F.; Türker, F.; Mamaç, R.Y.; Yenigün, M. FT3/FT4 ratio predicts non-alcoholic fatty liver disease independent of metabolic parameters in patients with euthyroidism and hypothyroidism. Clinics (Sao Paulo) 2016, 71, 221-225. [CrossRef]

72. van den Berg, E.H.; van Tienhoven-Wind, L.J.M.; Amini, M.; Schreuder, T.C.; Faber, K.N.; Blokzijl, H.; Dullaart, R.P. Higher free triiodothyronine is associated with non-alcoholic fatty liver disease in euthyroid subjects: The Lifelines Cohort Study. Metabolism 2017, 67, 62-71. [CrossRef] [PubMed]

73. Lingad-Sayas, R.C.; Montano, C.N.; Isidro, M.J.C. Prevalence of elevated TSH and its association with dyslipidemia and NAFLD among Filipino adult executive check-up patients in a tertiary hospital. Philipp. J. Intern. Med. 2017, 55, 1-8.

74. Mohanty, R.; Das, S.N.; Jena, A.K.; Behera, S.; Sahu, N.C.; Mohanty, B.; Suna, S.P.; Thatoi, P.K. Prevalence of non-alcoholic fatty liver disease in hypothyroidism in a tertiary care hospital in eastern India. J. Evol. Med. Dent. Sci. 2017, 6, 5589-5593. [CrossRef]

75. Kim, D.; Kim, W.; Joo, S.K.; Bae, J.M.; Kim, J.H.; Ahmed, A. Subclinical hypothyroidism and low-normal thyroid function are associated with nonalcoholic steatohepatitis and fibrosis. Clin. Gastroenterol. Hepatol. 2018, 16, 123-131. [CrossRef] [PubMed]

76. Lee, J.; Ha, J.; Jo, K.; Lim, D.J.; Lee, J.M.; Chang, S.A.; Kang, M.I.; Cha, B.Y.; Kim, M.H. Male-specific association between subclinical hypothyroidism and the risk of non-alcoholic fatty liver disease estimated by hepatic steatosis index: Korea National Health and Nutrition Examination Survey 2013 to 2015. Sci. Rep. 2018, 8, 15145. [CrossRef] [PubMed]

77. Jaruvongvanich, V.; Sanguankeo, A.; Upala, S. Nonalcoholic fatty liver disease is not associated with thyroid hormone levels and hypothyroidism: A systematic review and meta-analysis. Eur. Thyroid J. 2017, 6, $208-215$. [CrossRef] [PubMed]

78. He, W.; An, X.; Li, L.; Shao, X.; Li, Q.; Yao, Q.; Zhang, J.A. Relationship between hypothyroidism and non-alcoholic fatty liver disease: A systematic review and meta-analysis. Front. Endocrinol. 2017, 8, 335. [CrossRef] [PubMed]

79. Mantovani, A.; Nascimbeni, F.; Lonardo, A.; Zoppini, G.; Bonora, E.; Mantzoros, C.S.; Targher, G. Association Between Primary Hypothyroidism and Nonalcoholic Fatty Liver Disease: A Systematic Review and Meta-Analysis. Thyroid 2018, 28, 1270-1284. [CrossRef]

80. Guo, Z.; Li, M.; Han, B.; Qi, X. Association of non-alcoholic fatty liver disease with thyroid function: A systematic review and meta-analysis. Dig. Liver Dis. 2018, 50, 1153-1162. [CrossRef] [PubMed]

81. Lugari, S.; Mantovani, A.; Nascimbeni, F.; Lonardo, A. Hypothyroidism and nonalcoholic fatty liver disease-a chance association? Horm. Mol. Biol. Clin. Investig. 2018. [CrossRef] [PubMed]

82. Byrne, C.D.; Targher, G. NAFLD: a multisystem disease. J. Hepatol. 2015, 62, S47-S64. [CrossRef] [PubMed]

83. Yan, F.; Wang, Q.; Lu, M.; Chen, W.; Song, Y.; Jing, F.; Guan, Y.; Wang, L.; Lin, Y.; Bo, T.; et al. Thyrotropin increases hepatic triglyceride content through upregulation of SREBP-1c activity. J. Hepatol. 2014, 61, 1358-1364. [CrossRef] [PubMed] 
84. Bril, F.; Kadiyala, S.; Cusi, K. Re: “Association Between Primary Hypothyroidism and Nonalcoholic Fatty Liver Disease: A Systematic Review and Meta-Analysis” by Mantovani et al. (Thyroid 2018;28:1270-1284). Thyroid 2019, 29, 452. [CrossRef] [PubMed]

85. Liu, L.; Yu, Y.; Zhao, M.; Zheng, D.; Zhang, X.; Guan, Q.; Xu, C.; Gao, L.; Zhao, J.; Zhang, H. Benefits of levothyroxine replacement therapy on nonalcoholic fatty liver disease in subclinical hypothyroidism patients. Int. J. Endocrinol. 2017, 2017, 5753039. [CrossRef] [PubMed]

86. Bruinstroop, E.; Dalan, R.; Yang, C.; Bee, Y.M.; Chandran, K.; Cho, L.W.; Soh, S.B.; Teo, E.K.; Toh, S.A.; Leow, M.K.S.; et al. Low dose levothyroxine reduces intrahepatic lipid content in patients with type 2 diabetes mellitus and NAFLD. J. Clin. Endocrinol. Metab. 2018, 103, 2698-2706. [CrossRef] [PubMed]

87. Mintziori, G.; Poulakos, P.; Tsametis, C.; Goulis, D.G. Hypogonadism and non-alcoholic fatty liver disease. Minerva Endocrinol. 2017, 42, 145-150. [PubMed]

88. Haider, A.; Gooren, L.J.; Padungtod, P.; Saad, F. Improvement of the metabolic syndrome and of non-alcoholic liver steatosis upon treatment of hypogonadal elderly men with parenteral testosterone undecanoate. Exp. Clin. Endocrinol. Diabetes 2010, 118, 167-171. [CrossRef] [PubMed]

89. Seo, N.K.; Koo, H.S.; Haam, J.H.; Kim, H.Y.; Kim, M.J.; Park, K.C.; Park, K.S.; Kim, Y.S. Prediction of prevalent but not incident non-alcoholic fatty liver disease by levels of serum testosterone. J. Gastroenterol. Hepatol. 2015, 30, 1211-1216. [CrossRef] [PubMed]

90. Wang, W.B.; She, F.; Xie, L.F.; Yan, W.H.; Ouyang, J.Z.; Wang, B.A.; Ma, H.Y.; Zang, L.; Mu, Y.M. Evaluation of Basal Serum Adrenocorticotropic Hormone and Cortisol Levels and Their Relationship with Nonalcoholic Fatty Liver Disease in Male Patients with Idiopathic Hypogonadotropic Hypogonadism. Chin. Med. J. 2016, 129, 1147-1153. [CrossRef]

91. Barbonetti, A.; Caterina Vassallo, M.R.; Cotugno, M.; Felzani, G.; Francavilla, S.; Francavilla, F. Low testosterone and non-alcoholic fatty liver disease: Evidence for their independent association in men with chronic spinal cord injury. J. Spinal Cord Med. 2016, 39, 443-449. [CrossRef] [PubMed]

92. Gild, P.; Cole, A.P.; Krasnova, A.; Dickerman, B.A.; von Landenberg, N.; Sun, M.; Mucci, L.A.; Lipsitz, S.R.; Chun, F.K.; Nguyen, P.L.; et al. Liver Disease in Men Undergoing Androgen Deprivation Therapy for Prostate Cancer. J. Urol. 2018, 200, 573-581. [CrossRef] [PubMed]

93. Elsheikh, M.; Hodgson, H.J.; Wass, J.A.; Conway, G.S. Hormone replacement therapy may improve hepatic function in women with Turner's syndrome. Clin. Endocrinol. 2001, 55, 227-231. [CrossRef]

94. Bruno, S.; Maisonneuve, P.; Castellana, P.; Rotmensz, N.; Rossi, S.; Maggioni, M.; Persico, M.; Colombo, A.; Monasterolo, F.; Casadei-Giunchi, D.; et al. Incidence and risk factors for non-alcoholic steatohepatitis: prospective study of 5408 women enrolled in Italian tamoxifen chemoprevention trial. BMJ 2005, 330, 932. [CrossRef] [PubMed]

95. McKenzie, J.; Fisher, B.M.; Jaap, A.J.; Stanley, A.; Paterson, K.; Sattar, N. Effects of HRT on liver enzyme levels in women with type 2 diabetes: a randomized placebo-controlled trial. Clin. Endocrinol. 2006, 65, 40-44. [CrossRef] [PubMed]

96. Koulouri, O.; Ostberg, J.; Conway, G.S. Liver dysfunction in Turner's syndrome: prevalence, natural history and effect of exogenous oestrogen. Clin. Endocrinol. 2008, 69, 306-310. [CrossRef] [PubMed]

97. El-Mansoury, M.; Berntorp, K.; Bryman, I.; Hanson, C.; Innala, E.; Karlsson, A.; Landin-Wilhelmsen, K. Elevated liver enzymes in Turner syndrome during a 5-year follow-up study. Clin. Endocrinol. 2008, 68, 485-490. [CrossRef]

98. Gutierrez-Grobe, Y.; Ponciano-Rodríguez, G.; Ramos, M.H.; Uribe, M.; Méndez-Sánchez, N. Prevalence of non alcoholic fatty liver disease in premenopausal, posmenopausal and polycystic ovary syndrome women. The role of estrogens. Ann. Hepatol. 2010, 9, 402-409.

99. Yang, J.D.; Abdelmalek, M.F.; Pang, H.; Guy, C.D.; Smith, A.D.; Diehl, A.M.; Suzuki, A. Gender and menopause impact severity of fibrosis among patients with nonalcoholic steatohepatitis. Hepatology 2014, 59, 1406-1414. [CrossRef]

100. Hanew, K. Women with Turner syndrome are at high risk of lifestyle-related disease-From questionnaire surveys by the Foundation for Growth Science in Japan. Endocr. J. 2016, 63, 449-456. [CrossRef]

101. Yang, Y.J.; Kim, K.M.; An, J.H.; Lee, D.B.; Shim, J.H.; Lim, Y.S.; Lee, H.C.; Lee, Y.S.; Ahn, J.H.; Jung, K.H.; et al. Clinical significance of fatty liver disease induced by tamoxifen and toremifene in breast cancer patients. Breast 2016, 28, 67-72. [CrossRef] [PubMed] 
102. Klair, J.S.; Yang, J.D.; Abdelmalek, M.F.; Guy, C.D.; Gill, R.M.; Yates, K.; Unalp-Arida, A.; Lavine, J.E.; Clark, J.M.; Diehl, A.M.; et al. Nonalcoholic Steatohepatitis Clinical Research Network. A longer duration of estrogen deficiency increases fibrosis risk among postmenopausal women with nonalcoholic fatty liver disease. Hepatology 2016, 64, 85-91. [CrossRef] [PubMed]

103. Lonardo, A.; Nascimbeni, F.; Ballestri, S.; Fairweather, D.L.; Win, S.; Than, T.A.; Manal, F.; Abdelmalek, M.F.; Suzuki, A. Sex Differences in NAFLD: State of the Art and Identification of Research Gaps. Hepatology 2019. [CrossRef] [PubMed]

104. Matsuo, K.; Gualtieri, M.R.; Cahoon, S.S.; Jung, C.E.; Paulson, R.J.; Shoupe, D.; Muderspach, L.I.; Wakatsuki, A.; Wright, J.D.; Roman, L.D. Surgical menopause and increased risk of nonalcoholic fatty liver disease in endometrial cancer. Menopause 2016, 23, 189-196. [CrossRef] [PubMed]

105. Wang, Z.; Xu, M.; Hu, Z.; Shrestha, U.K. Prevalence of nonalcoholic fatty liver disease and its metabolic risk factors in women of different ages and body mass index. Menopause 2015, 22, 667-673. [CrossRef] [PubMed]

106. Venetsanaki, V.; Polyzos, S.A. Menopause and non-alcoholic fatty liver disease: A review focusing on therapeutic perspective. Curr. Vasc. Pharmacol. 2018. [CrossRef] [PubMed]

107. Kamada, Y.; Kiso, S.; Yoshida, Y.; Chatani, N.; Kizu, T.; Hamano, M.; Tsubakio, M.; Takemura, T.; Ezaki, H.; Hayashi, N.; et al. Estrogen deficiency worsens steatohepatitis in mice fed high-fat and high-cholesterol diet. Am. J. Physiol. Gastrointest. Liver Physiol. 2011, 301, G1031-G1043. [CrossRef] [PubMed]

108. Shen, M.; Shi, H. Sex Hormones and Their Receptors Regulate Liver Energy Homeostasis. Int. J. Endocrinol. 2015, 2015, 294278. [CrossRef]

109. Sakr, H.F.; Hussein, A.M.; Eid, E.A.; AIKhateeb, M. Possible mechanisms underlying fatty liver in a rat model of male hypogonadism: A protective role for testosterone. Steroids 2018, 135, 21-30. [CrossRef]

110. Maffei, L.; Murata, Y.; Rochira, V.; Tubert, G.; Aranda, C.; Vazquez, M.; Clyne, C.D.; Davis, S.; Simpson, E.R.; Carani, C. Dysmetabolic syndrome in a man with a novel mutation of the aromatase gene: effects of testosterone, alendronate, and estradiol treatment. J. Clin. Endocrinol. Metab. 2004, 89, 61-70. [CrossRef]

111. Maffei, L.; Rochira, V.; Zirilli, L.; Antunez, P.; Aranda, C.; Fabre, B.; Simone, M.L.; Pignatti, E.; Simpson, E.R.; Houssami, S.; et al. A novel compound heterozygous mutation of the aromatase gene in an adult man: reinforced evidence on the relationship between congenital oestrogen deficiency, adiposity and the metabolic syndrome. Clin. Endocrinol. 2007, 67, 218-224. [CrossRef] [PubMed]

112. Kander, M.C. Gender difference in oxidative stress: a new look at the mechanisms for cardiovascular diseases. J. Cell Mol. Med. 2017, 21, 1024-1032. [CrossRef] [PubMed]

113. Chukijrungroat, N. Hepatic FGF21 mediates sex differences in high-fat high-fructose diet-induced fatty liver. Am. J. Physiol. Endocrinol. Metab. 2017, 313, E203-E212. [CrossRef] [PubMed]

114. Harada, N. Hypogonadism alters cecal and fecal microbiota in male mice. Gut Microbes 2016, 7, 533-539. [CrossRef] [PubMed]

115. Charlton, M.; Angulo, P.; Chalasani, N.; Merriman, R.; Viker, K.; Charatcharoenwitthaya, P.; Sanderson, S.; Gawrieh, S.; Krishnan, A.; Lindor, K. Low circulating levels of dehydroepiandrosterone in histologically advanced nonalcoholic fatty liver disease. Hepatology 2008, 47, 484-492. [CrossRef] [PubMed]

116. Sumida, Y.; Yonei, Y.; Kanemasa, K.; Hara, T.; Inada, Y.; Sakai, K.; Imai, S.; Hibino, S.; Yamaguchi, K.; Mitsuyoshi, H.; et al. Lower circulating levels of dehydroepiandrosterone, independent of insulin resistance, is an important determinant of severity of non-alcoholic steatohepatitis in Japanese patients. Hepatol. Res. 2010, 40, 901-910. [CrossRef]

117. Koga, M.; Saito, H.; Mukai, M.; Saibara, T.; Kasayama, S. Serum dehydroepiandrosterone sulphate levels in patients with non-alcoholic fatty liver disease. Intern. Med. 2011, 50, 1657-1661. [CrossRef]

118. Koehler, E.; Swain, J.; Sanderson, S.; Krishnan, A.; Watt, K.; Charlton, M. Growth hormone, dehydroepiandrosterone and adiponectin levels in non-alcoholic steatohepatitis: an endocrine signature for advanced fibrosis in obese patients. Liver Int. 2012, 32, 279-286. [CrossRef]

119. Tokushige, K.; Hashimoto, E.; Kodama, K.; Tobari, M.; Matsushita, N.; Kogiso, T.; Taniai, M.; Torii, N.; Shiratori, K.; Nishizaki, Y.; et al. Serum metabolomic profile and potential biomarkers for severity of fibrosis in nonalcoholic fatty liver disease. J. Gastroenterol. 2013, 48, 1392-1400. [CrossRef]

120. Zhou, J.H.; Cai, J.J.; She, Z.G.; Li, H.L. Noninvasive evaluation of nonalcoholic fatty liver disease: Current evidence and practice. World J. Gastroenterol. 2019, 25, 1307-1326. [CrossRef]

121. Nascimbeni, F.; Pais, R.; Bellentani, S.; Day, C.P.; Ratziu, V.; Loria, P.; Lonardo, A. From NAFLD in clinical practice to answers from guidelines. J. Hepatol. 2013, 59, 859-871. [CrossRef] [PubMed] 
122. Nascimbeni, F.; Ballestri, S.; Machado, M.V.; Mantovani, A.; Cortez-Pinto, H.; Targher, G.; Lonardo, A. Clinical relevance of liver histopathology and different histological classifications of NASH in adults. Expert Rev. Gastroenterol. Hepatol. 2018, 12, 351-367. [CrossRef] [PubMed]

123. Khera, M.; Broderick, G.A.; Carson, C.C.; Dobs, A.S.; Faraday, M.M.; Goldstein, I.; Hakim, L.S.; Hellstrom, W.J.; Kacker, R.; Köhler, T.S.; et al. Adult-Onset Hypogonadism. Mayo Clin. Proc. 2016, 91, 908-926. [CrossRef]

124. Russell, N.; Grossmann, M. MECHANISMS IN ENDOCRINOLOGY: Estradiol as a male hormone. Eur. J. Endocrinol. 2019. [CrossRef] [PubMed]

125. Sigalos, J.T.; Pastuszak, A.W.; Khera, M. Hypogonadism: Therapeutic Risks, Benefits, and Outcomes. Med. Clin. N. Am. 2018, 102, 361-372. [CrossRef] [PubMed]

126. Klein, K.O.; Rosenfield, R.L.; Santen, R.J.; Gawlik, A.M.; Backeljauw, P.F.; Gravholt, C.H.; Sas, T.C.J.; Mauras, N. Estrogen Replacement in Turner Syndrome: Literature Review and Practical Considerations. J. Clin. Endocrinol. Metab. 2018, 103, 1790-1803. [CrossRef]

127. Ballestri, S.; Mantovani, A.; Nascimbeni, F.; Lugari, S.; Lonardo, A. Extra-hepatic manifestations and complications of NAFLD. Future Med. Chem.. (In Press).

128. Takahashi, Y. The Role of Growth Hormone and Insulin-Like Growth Factor-I in the Liver. Int. J. Mol. Sci. 2017, 18, 1447. [CrossRef] [PubMed]

129. Vijayakumar, A.; Novosyadlyy, R.; Wu, Y.; Yakar, S.; LeRoith, D. Biological effects of growth hormone on carbohydrate and lipid metabolism. Growth Horm. IGF Res. 2010, 20, 1-7. [CrossRef] [PubMed]

130. Kim, S.H.; Park, M.J. Effects of growth hormone on glucose metabolism and insulin resistance in human. Ann. Pediatr. Endocrinol. Metab. 2017, 22, 145-152. [CrossRef]

131. Le Roith, D.; Bondy, C.; Yakar, S.; Liu, J.L.; Butler, A. The somatomedin hypothesis: 2001. Endocr. Rev. 2001, 22, 53-74. [CrossRef] [PubMed]

132. Savage, M.O. Insulin-like growth factors, nutrition and growth. World Rev. Nutr. Diet. 2013, 106, 52-59. [PubMed]

133. Thomas, J.D.; Monson, J.P. Adult GH deficiency throughout lifetime. Eur. J. Endocrinol. 2009, 1, S97-S106. [CrossRef] [PubMed]

134. Ichikawa, T.; Nakao, K.; Hamasaki, K.; Furukawa, R.; Tsuruta, S.; Ueda, Y.; Taura, N.; Shibata, H.; Fujimoto, M.; Toriyama, K.; et al. Role of growth hormone, insulin-like growth factor 1 and insulin-like growth factor-binding protein 3 in development of non-alcoholic fatty liver disease. Hepatol. Int. 2007, 1, 287-294. [CrossRef]

135. Xu, L.; Xu, C.; Yu, C.; Miao, M.; Zhang, X.; Zhu, Z.; Ding, X.; Li, Y. Association between serum growth hormone levels and nonalcoholic fatty liver disease: a cross-sectional study. PLoS ONE 2012, 7, e44136. [CrossRef]

136. Lonardo, A.; Loria, P.; Leonardi, F.; Ganazzi, D.; Carulli, N. Growth hormone plasma levels in nonalcoholic fatty liver disease. Am. J. Gastroenterol. 2002, 97, 1071-1072. [CrossRef] [PubMed]

137. Arturi, F.; Succurro, E.; Procopio, C.; Pedace, E.; Mannino, G.C.; Lugarà, M.; Procopio, T.; Andreozzi, F.; Sciacqua, A.; Hribal, M.L.; et al. Nonalcoholic fatty liver disease is associated with low circulating levels of insulin-like growth factor-I. J. Clin. Endocrinol. Metab. 2011, 96, E1640-E1644. [CrossRef]

138. Liang, S.; Yu, Z.; Song, X.; Wang, Y.; Li, M.; Xue, J. Reduced Growth Hormone Secretion is Associated with Nonalcoholic Fatty Liver Disease in Obese Children. Horm. Metab. Res. 2018, 50, 250-256. [CrossRef]

139. Sumida, Y.; Yonei, Y.; Tanaka, S.; Mori, K.; Kanemasa, K.; Imai, S.; Taketani, H.; Hara, T.; Seko, Y.; Ishiba, H.; et al. Lower levels of insulin-like growth factor-1 standard deviation score are associated with histological severity of non-alcoholic fatty liver disease. Hepatol. Res. 2015, 45, 771-781. [CrossRef]

140. Dichtel, L.E.; Corey, K.E.; Misdraji, J.; Bredella, M.A.; Schorr, M.; Osganian, S.A.; Young, B.J.; Sung, J.C.; Miller, K.K. The association between IGF-1 levels and the histological severity of Nonalcoholic Fatty Liver Disease. Clin. Transl. Gastroenterol. 2017, 8, e217. [CrossRef]

141. Chishima, S.; Kogiso, T.; Matsushita, N.; Hashimoto, E.; Tokushige, K. The Relationship between the Growth Hormone/Insulin-like Growth Factor System and the Histological Features of Nonalcoholic Fatty Liver Disease. Intern. Med. 2017, 56, 473-480. [CrossRef] [PubMed]

142. Rufinatscha, K.; Ress, C.; Folie, S.; Haas, S.; Salzmann, K.; Moser, P.; Dobner, J.; Weiss, G.; Iruzubieta, P.; Arias-Loste, M.T.; et al. Metabolic effects of reduced growth hormone action in fatty liver disease. Hepatol. Int. 2018, 12, 474-481. [CrossRef] [PubMed] 
143. Adams, L.A.; Feldstein, A.; Lindor, K.D.; Angulo, P. Nonalcoholic fatty liver disease among patients with hypothalamic and pituitary dysfunction. Hepatology 2004, 39, 909-914. [CrossRef] [PubMed]

144. Nishizawa, H.; Iguchi, G.; Murawaki, A.; Fukuoka, H.; Hayashi, Y.; Kaji, H.; Yamamoto, M.; Suda, K.; Takahashi, M.; Seo, Y.; et al. Nonalcoholic fatty liver disease in adult hypopituitary patients with GH deficiency and the impact of GH replacement therapy. Eur. J. Endocrinol. 2012, 167, 67-74. [CrossRef] [PubMed]

145. Ichikawa, T.; Hamasaki, K.; Ishikawa, H.; Ejima, E.; Eguchi, K.; Nakao, K. Non-alcoholic steatohepatitis and hepatic steatosis in patients with adult onset growth hormone deficiency. Gut 2003, 52, 914. [CrossRef] [PubMed]

146. Hong, J.W.; Kim, J.Y.; Kim, Y.E.; Lee, E.J. Metabolic parameters and nonalcoholic fatty liver disease in hypopituitary men. Horm. Metab. Res. 2011, 43, 48-54. [CrossRef] [PubMed]

147. Gardner, C.J.; Irwin, A.J.; Daousi, C.; McFarlane, I.A.; Joseph, F.; Bell, J.D.; Thomas, E.L.; Adams, V.L.; Kemp, G.J.; Cuthbertson, D.J. Hepatic steatosis, GH deficiency and the effects of GH replacement: a Liverpool magnetic resonance spectroscopy study. Eur. J. Endocrinol. 2012, 166, 993-1002. [CrossRef] [PubMed]

148. Meienberg, F.; Yee, M.; Johnston, D.; Cox, J.; Robinson, S.; Bell, J.D.; Thomas, E.L.; Taylor-Robinson, S.D.; Godsland, I. Liver fat in adults with GH deficiency: comparison to matched controls and the effect of GH replacement. Clin. Endocrinol. 2016, 85, 76-84. [CrossRef]

149. Gilliland, T.; Dufour, S.; Shulman, G.I.; Petersen, K.F.; Emre, S.H. Resolution of non-alcoholic steatohepatitis after growth hormone replacement in a pediatric liver transplant patient with panhypopituitarism. Pediatr. Transplant. 2016, 20, 1157-1163. [CrossRef]

150. de la Garza, R.G.; Morales-Garza, L.A.; Martin-Estal, I.; Castilla-Cortazar, I. Insulin-Like Growth Factor-1 Deficiency and Cirrhosis Establishment. J. Clin. Med. Res. 2017, 9, 233-247. [CrossRef]

151. Adamek, A.; Kasprzak, A. Insulin-Like Growth Factor (IGF) System in Liver Diseases. Int. J. Mol. Sci. 2018, 19, 1308. [CrossRef] [PubMed]

152. Fan, Y.; Fang, X.; Tajima, A.; Geng, X.; Ranganathan, S.; Dong, H.; Trucco, M.; Sperling, M.A. Evolution of hepatic steatosis to fibrosis and adenoma formation in liver-specific growth hormone receptor knockout mice. Front. Endocrinol. 2014, 5, 218. [CrossRef] [PubMed]

153. Cordoba-Chacon, J.; Majumdar, N.; List, E.O.; Diaz-Ruiz, A.; Frank, S.J.; Manzano, A.; Bartrons, R.; Puchowicz, M.; Kopchick, J.J.; Kineman, R.D. Growth Hormone Inhibits Hepatic De Novo Lipogenesis in Adult Mice. Diabetes 2015, 64, 3093-3103. [CrossRef] [PubMed]

154. Sos, B.C.; Harris, C.; Nordstrom, S.M.; Tran, J.L.; Balázs, M.; Caplazi, P.; Febbraio, M.; Applegate, M.A.; Wagner, K.U.; Weiss, E.J. Abrogation of growth hormone secretion rescues fatty liver in mice with hepatocyte-specific deletion of JAK2. J. Clin. Invest. 2011, 121, 1412-1423. [CrossRef] [PubMed]

155. Barclay, J.L.; Nelson, C.N.; Ishikawa, M.; Murray, L.A.; Kerr, L.M.; McPhee, T.R.; Powell, E.E.; Waters, M.J. GH-dependent STAT5 signaling plays an important role in hepatic lipid metabolism. Endocrinology 2011, 152, 181-192. [CrossRef]

156. Nishizawa, H.; Takahashi, M.; Fukuoka, H.; Iguchi, G.; Kitazawa, R.; Takahashi, Y. GH-independent IGF-1 action is essential to prevent the development of nonalcoholic steatohepatitis in a GH-deficient rat model. Biochem. Biophys. Res. Commun. 2012, 423, 295-300. [CrossRef] [PubMed]

157. Puche, J.E.; García-Fernández, M.; Muntané, J.; Rioja, J.; González-Barón, S.; Castilla Cortazar, I. Low doses of insulin-like growth factor-I induce mitochondrial protection in aging rats. Endocrinology 2008, 149, 2620-2627. [CrossRef] [PubMed]

158. Karamitri, A.; Jockers, R. Melatonin in type 2 diabetes mellitus and obesity. Nat. Rev. Endocrinol. 2019, 15, 105-125. [CrossRef]

159. Zhou, H.; Du, W.; Li, Y.; Shi, C.; Hu, N.; Ma, S.; Wang, W.; Ren, J. Effects of melatonin on fatty liver disease: The role of NR4A1/DNA-PKcs/p53 pathway, mitochondrial fission, and mitophagy. J. Pineal Res. 2018, 64, e12450. [CrossRef]

160. Takahashi, Y.; Iida, K.; Takahashi, K.; Yoshioka, S.; Fukuoka, H.; Takeno, R.; Imanaka, M.; Nishizawa, H.; Takahashi, M.; Seo, Y.; et al. Growth hormone reverses nonalcoholic steatohepatitis in a patient with adult growth hormone deficiency. Gastroenterology 2007, 132, 938-943. [CrossRef]

161. Nishizawa, H.; Iguchi, G.; Fukuoka, H.; Takahashi, M.; Suda, K.; Bando, H.; Matsumoto, R.; Yoshida, K.; Odake, Y.; Ogawa, W.; et al. IGF-I induces senescence of hepatic stellate cells and limits fibrosis in a p53-dependent manner. Sci. Rep. 2016, 6, 34605. [CrossRef] [PubMed] 
162. Attanasio, A.F.; Bates, P.C.; Ho, K.K.; Webb, S.M.; Ross, R.J.; Strasburger, C.J.; Bouillon, R.; Crowe, B.; Selander, K.; Valle, D.; et al. Hypoptiuitary Control and Complications Study International Advisory Board. Human growth hormone replacement in adult hypopituitary patients: long-term effects on body composition and lipid status-3-year results from the Hypo CCS Database. J. Clin. Endocrinol. Metab. 2002, 87, 1600-1606.

163. Molitch, M.E.; Clemmons, D.R.; Malozowski, S.; Merriam, G.R.; Vance, M.L. Endocrine Society. Evaluation and treatment of adult growth hormone deficiency: An Endocrine Society clinical practice guideline. J. Clin. Endocrinol. Metab. 2011, 96, 1587-1609. [CrossRef]

164. Takano, S.; Kanzaki, S.; Sato, M.; Kubo, T.; Seino, Y. Effect of growth hormone on fatty liver in panhypopituitarism. Arch. Dis. Child. 1997, 76, 537-538. [CrossRef] [PubMed]

165. Matsumoto, R.; Fukuoka, H.; Iguchi, G.; Nishizawa, H.; Bando, H.; Suda, K.; Takahashi, M.; Takahashi, Y. Long-term effects of growth hormone replacement therapy on liver function in adult patients with growth hormone deficiency. Growth Horm. IGF Res. 2014, 24, 174-179. [CrossRef] [PubMed]

166. Sesmilo, G.; Biller, B.M.; Llevadot, J.; Hayden, D.; Hanson, G.; Rifai, N.; Klibanski, A. Effects of growth hormone administration on inflammatory and other cardiovascular risk markers in men with growth hormone deficiency. A randomized, controlled clinical trial. Ann. Intern Med. 2000, 33, 111-122. [CrossRef]

167. Fukuda, I.; Hizuka, N.; Yasumoto, K.; Morita, J.; Kurimoto, M.; Takano, K. Metabolic co-morbidities revealed in patients with childhood-onset adult GH deficiency after cessation of GH replacement therapy for short stature. Endocr. J. 2008, 55, 977-984. [CrossRef]

168. Zhang, H.; Liu, Y.; Wang, L.; Li, Z.; Zhang, H.; Wu, J.; Rahman, N.; Guo, Y.; Li, D.; Li, N.; et al. Differential effects of estrogen/androgen on the prevention of nonalcoholic fatty liver disease in the male rat. J. Lipid Res. 2013, 54, 345-357. [CrossRef]

169. Grossmann, M.; Wierman, M.E.; Angus, P.; Handelsman, D.J. Reproductive Endocrinology of Nonalcoholic Fatty Liver Disease. Endocr. Rev. 2019, 40, 417-446. [CrossRef]

170. Li, J.; Su, J.M.; Zeng, X.J. Is primary biliary cirrhosis another example of an immune-mediated complication of klinefelter syndrome? J. Clin. Rheumatol. 2004, 10, 286-287. [CrossRef]

171. Tian, Y.; Wang, C.; Liu, J.X.; Wang, H.H. Primary Biliary Cirrhosis-Related Autoimmune Hemolytic Anemia: Three Case Reports and Review of the Literature. Case Rep. Gastroenterol. 2009, 3, 240-247. [CrossRef] [PubMed]

172. Machlab, S.; Miquel, M.; Voltà, T.; Escoda, M.R.; Vergara, M. Turner syndrome as a cause of liver cirrhosis. Gastroenterol. Hepatol. 2018, 41, 308-309. [CrossRef] [PubMed] 